\title{
NEOTECTONICS AND INFERRED MOVEMENTS IN CANADA
}

\author{
HENRY S. HASEGAWA
}

\begin{abstract}
HASEGAWA, HENRY S., 1988: Neotectonics and inferred movements in Canada. Bull. Geol. Soc. Finland 60, Part 1, 3-25.

Neotectonic movements in Canada are due to a variety of causes. Within the Canadian Shield (craton) postglacial rebound appears to be the main contributor. Along the tectonically active western continental margin, plate subduction and transcurrent plate motion are taking place. Further inland there is a region where mantle upwelling is probably the dominant neotectonic process. Along many parts of the passive continental slopes, unconsolidated sediments are being deposited at a rate faster than isostatic adjustments can take place. Postglacial rebound has a strong influence on seismicity in northeastern Canada (Baffin Island-Baffin Bay region). Seismicity along the southeast (St. Lawrence Valley) appears to be due to a reactivation of ancient zones of weakness by the neotectonic stress field; postglacial rebound stress can, at the most, act as a trigger mechanism for seismicity in this region.

Long wavelength phenomena that are related to glacial loading-unloading and postglacial rebound can be represented by an elastic-viscoelastic lithosphere and asthenosphere. However, the spatio-temporal behaviour of the pattern of shortwavelength, nonlinear phenomena to postglacial rebound stress and strain depends on the characteristics of these heterogeneities (e.g. faults, blocks and intrusions). Consequently, in structurally heterogeneous regions in Canada and Fennoscandia with similar types of fault patterns and block geometry, a similar spatio- temporal history of postglacial fault offsets and block movements should occur. In other regions where the structural heterogeneities are different, different types and degrees of postglacial movement can be expected.
\end{abstract}

Key words: neotectonics, uplifts, glacial geology, isostacy, seismicity, mass movements, faults, Holocene, Canada.

Henry S. Hasegawa: Geological Survey of Canada, Energy, Mines and Resources, Ottawa, Canada.

\section{Introduction}

In Canada a variety of neotectonic processes have been identified but associated movements are often based on indirect evidence or inferences. One of the direct indicators of current movement in the upper crust is seismicity. Fig. 1 shows the distribution of seismic activity to 1986, as listed in Canadian earthquake catalogues (Seismological Service of Canada, Energy, Mines and
Resources). Superimposed are dashed outlines and (mnemonic) labels of some of the prominent trends that are discussed in later sections.

Neotectonic processes manifest themselves in diverse forms. Along the active circum-Pacific (CP) margin, plate subduction is occurring along the southwestern part and transcurrent plate motion to the north (Riddihough 1977). Along the passive continental margins, sediment loading is occurring along the continental slopes (Sobczak 


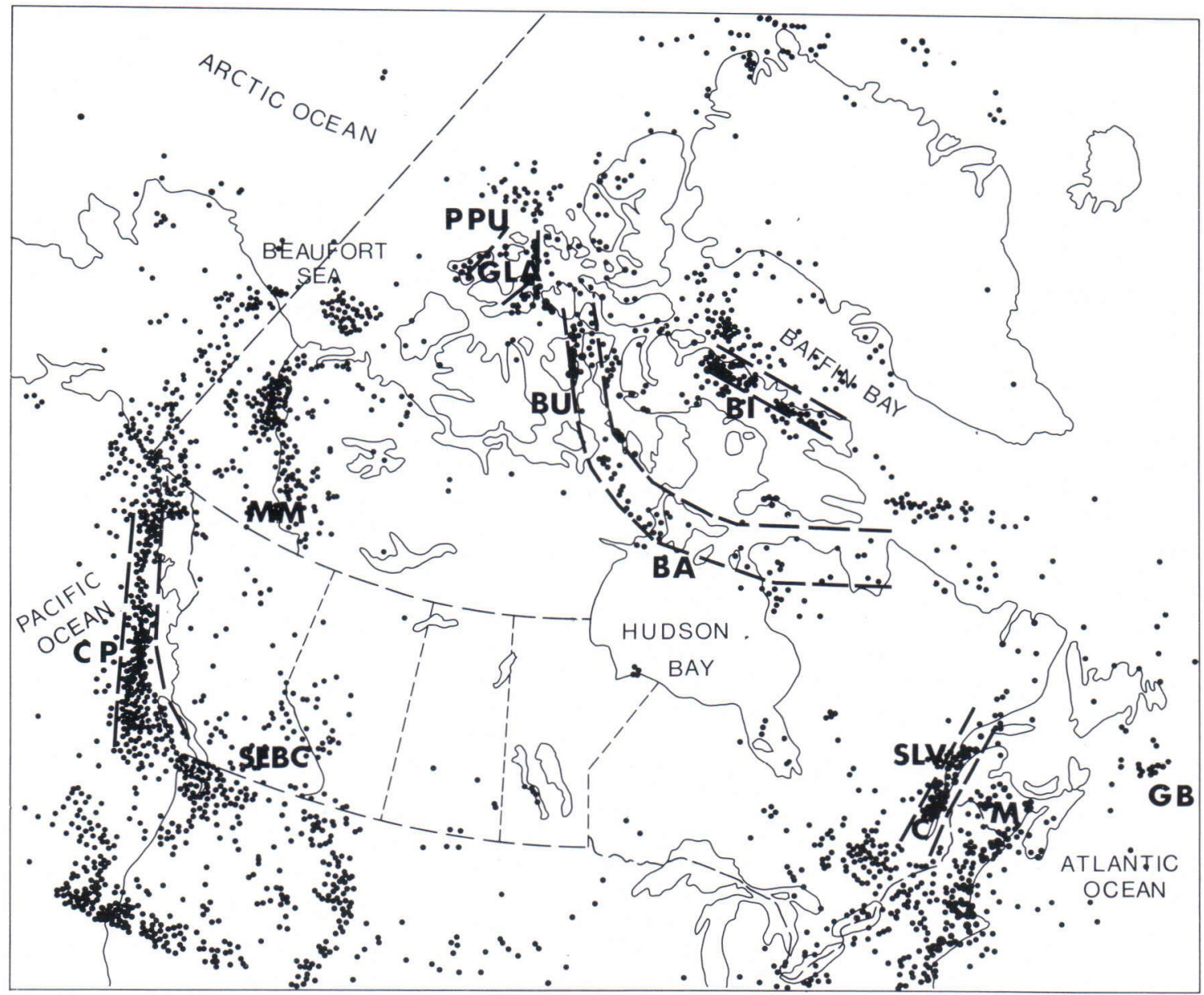

Fig. 1. Seismicity to end of 1986 superimposed on map of Canada with active neotectonic regions discussed in text represented by either dashed outlines or mnemonic labels.

1975 ) and is modifying the underlying deviatoric stress field (Hasegawa et al. 1979). Postglacial rebound appears to have a strong influence on seismic activity along the northeast margin in the Baffin Island (BI)-Baffin Bay region (Sleep et al. 1988). A major submarine landslide has occurred along the southeast margin, in the Grand Banks (GB) region (Doxsee 1948). Geophysical data indicate mantle upwelling in South Eastern British Columbia (SEBC) (Gough 1986). In the northern interior of the craton along the curvilinear, positive (uplift) basement trend, the Boothia Uplift-Bell Arch (BU-BA), weak zones are being reactivated by the neotectonic stress regime (Basham et al. 1977). To the southeast along the St. Lawrence Valley (SLV), faults from previous tectonic orogenies such as the opening of the Proto-Atlantic Ocean (Kumarapeli and Saull 1966) are being reactivated by the neotectonic stress field. On a more local scale, there is an anomalous subsidence zone in an ambient uplift zone along the St. Lawrence Valley (Frost and Lilly 1966), a reactivation of magmatic intrusion in the Miramichi (M) region of the eastern Maritimes (Wetmiller et al. 1984) and diabase intrusions into the lower crust along 
the Gustaf-Lougheed Arch (GLA) in the Arctic Archipelago (Forsyth et al. 1979). Thus neotectonic processes due to a variety of geophysical processes are triggering seismicity.

The main purpose of this overview is to discuss the principal causative factors and relevant vertical movement of the more prominent neotectonic processes mentioned previously. Thus there is no attempt to present a detailed account of the neotectonics or the seismotectonics of any of the selected regions. Since postglacial rebound tends to dominate on-going vertical movement in the central (craton) part, the respective roles of postglacial rebound and tectonic stresses with regards to the seismicity of prominent seismic zones within and bordering the craton are discussed in greater detail. Finally, a synopsis of direct measures of ground movement in Canada is presented (e.g. Vanicek and Nagy 1981) and compared with postglacial and tectonic movements (e.g. cf. Lambert and Vanicek 1979).

\section{Seismicity}

The spatio-temporal pattern of prominent seismic trends is indicative of the degree of structural heterogeneity (Mogi 1967, p. 43) as illustrated in Fig. 2, as well as the rate of buildup of stress and strain. An empirical relation that comes closest to quantifying this classification is the (Gutenberg and Richter 1944, 1954) magnitude-frequency relation $\log \mathrm{N}=\mathrm{a}-\mathrm{bM}$, where $\mathrm{N}$ is the number of earthquakes with magnitude equal to or greater than $\mathrm{M}$, a is a constant and $\mathrm{b}$ is indicative of the proportion of large versus small events. For the most common type of earthquake, Type 2 events, b $\sim 1$ (Mogi 1985, p. 112). For Type 1 events, $b<1$, which implies a higher proportion of larger magnitudes as compared with Type 2 events; examples are extensive interplate regions that are $» l o c k e d »$ over time spans of the order of 100 years (e.g. northern part of $\mathrm{CP}$ region in Fig. 1) and intraplate regions where a high level of stress and strain
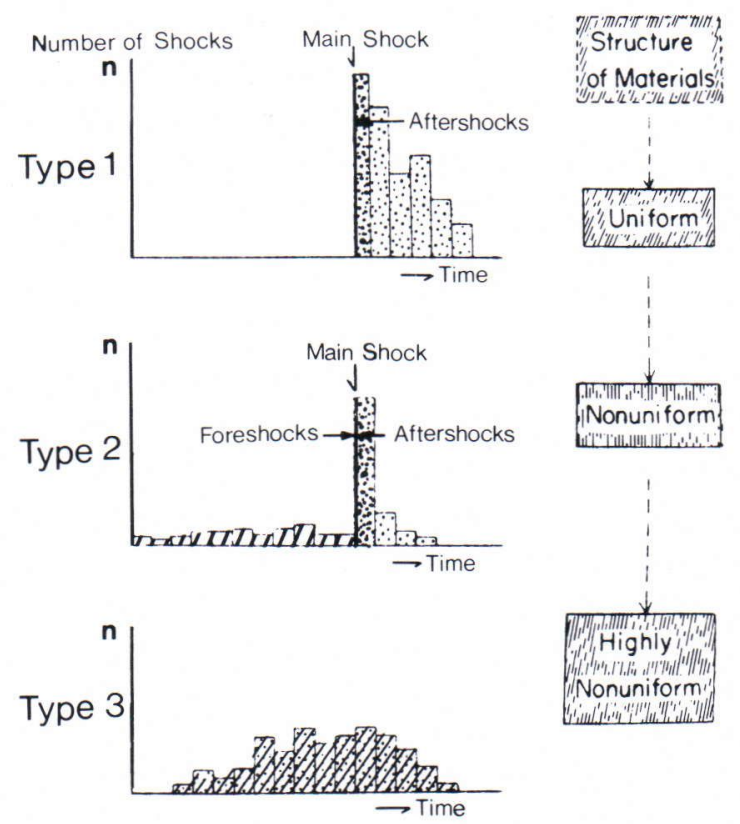

Fig. 2. Three types of earthquake sequences and associated structural heterogeneities (from Mogi 1967).

can build up over a sufficient lateral or areal extent (e.g. MacKenzie Mountains (MM), Charlevoix (C) region and northwestern Baffin Bay in Fig. 1). Type 3 events $(b>1)$ typify heterogeneous, weakened regions, incapable of storing a large, extensive buildup of stress and strain (e.g. microearthquake swarm along Prince Patrick Uplift (PPU) in Fig. 1; Smith et al. 1968). There are other types of earthquakes that fall into a category that is in between Type 1 and Type 2 earthquakes. An example is a very large earthquake with significant foreshock activity.

Other diagnostic information on the nature of the seismotectonic regime are as follows. Regions where faults intersect are often the locus of stress concentrations and, frequently, large earthquakes (Keilis-Borok and Press 1980, p. 55; Talwani 1986, p. 13; Hasegawa 1986, p. 90). Stress-strain concentrations often migrate laterally after a large earthquake, thereby initiating faulting in an adjacent seismotectonic province (Kasahara 1979, p. 330). The horizontal component of a stress field can migrate upwards, thereby ampli- 
fying stress in the upper crust and reducing stress in the underlying (lower crust and upper mantle) regions (Hasegawa et al. 1985, p. 3645). Zoback and Zoback (1986, p. 13) propose that a vertical, upward migration of the stress field is necessary in certain seismically active areas of eastern United States because the rate of (horizontal) stress buildup due to plate tectonic (mid-Atlantic spreading ridge) stress appears to be inadequate. A reactivation of ancient zones of weakness by the present stress field appears to be a major contributor to seismic activity along several major trends (e.g. BU-BA and SLV in Fig. 1).

The extent to which postglacial rebound influences seismicity in Canada depends on the structural heterogeneity of the crust and its response to repeated episodes of glacial loading and unloading. The strongest correlation between rebound stress and seismicity is observed in the Baffin Island (BI) and Baffin Bay region (Wetmiller and Forsyth 1982; Sleep et al. 1988). A moderate correlation is observed along the Boothia Uplift-Bell Arch (BU-BA) (Wetmiller and Forsyth 1982, p. 272). In other seismically active regions such as the St. Lawrence Valley (SLV), the correlation appears to be much weaker, as tectonic and local stresses appear to dominate (e.g. see Hasegawa 1986, pp. 85-88). In general, the longer the wavelength of the postglacial phenomenon, the less relevant local heterogeneities become. For this case (e.g. Canadian Shield) the overall spatio-temporal behaviour of rebound phenomena can be represented by an elastic crust overlying a viscoelastic upper and lower mantle (e.g. see Peltier 1986, p. 9115; Peltier and Wu 1982, p. 732).

\section{Plate subduction}

A schematic diagram of oceanic plate subduction and transform plate motion along the circum-Pacific rim bordering western Canada is shown in Fig. 3. Associated vertical ground movement is, on the average, $2 \mathrm{~mm} / \mathrm{yr}$ uplift along central Vancouver Island and 1 to $2 \mathrm{~mm} /$ yr subsidence to the east (Riddihough 1982, pp. 321-325). Similar trends are observed by Vanicek and Nagy (1981, p. 81) using relevelling and tide gauge data. A detailed analysis of vertical movement on Vancouver Island (Rogers and Hasegawa 1978, p. 668; Dragert 1987, p. 689) indicates pre-, co- and post-earthquake deformation adjacent to the fault of the M 7.2 central Vancouver Island earthquake of 1949. The general trend of vertical movement is compatible with and dominated by plate tectonics.

Analysis of postglacial rebound indicates current uplift along the west coast and further inland (Peltier 1986, p. 9115). Thus along the western coastline and offshore, neotectonic movements are dominated by plate tectonics. However, further inland as the effects of plate subduction decrease, other phenomena such as postglacial rebound and, in one location (see SEBC in Fig. 1) mantle upwelling, may govern current vertical movement.

\section{Mantle upwelling}

From an analysis of geophysical, geological and petrological data from the Cordillera of southeastern British Columbia (SEBC in Fig. 1), Gough (1986) concludes that mantle upwelling is taking place in this region. Fig. 4 shows, schematically, the location of mantle upwelling and associated flow and stress pattern in the mantle. The high heat flow, high electrical conductance, low density and thick low-velocity layer present strong evidence for partial melt. A vertical west-to-east profile of heat flow across southern Canada, as shown in Fig. 5, indicates a maximum in this region.

Measurements of vertical motion along this profile indicate a maximum in the region of mantle upwelling. The measured peak in uplift rate is $7 \mathrm{~mm} / \mathrm{yr}$. (Vanicek and Nagy 1980, p. 38). Postglacial uplift rate (Peltier 1986, p. 9115) is about one order-of-magnitude less in this region. 


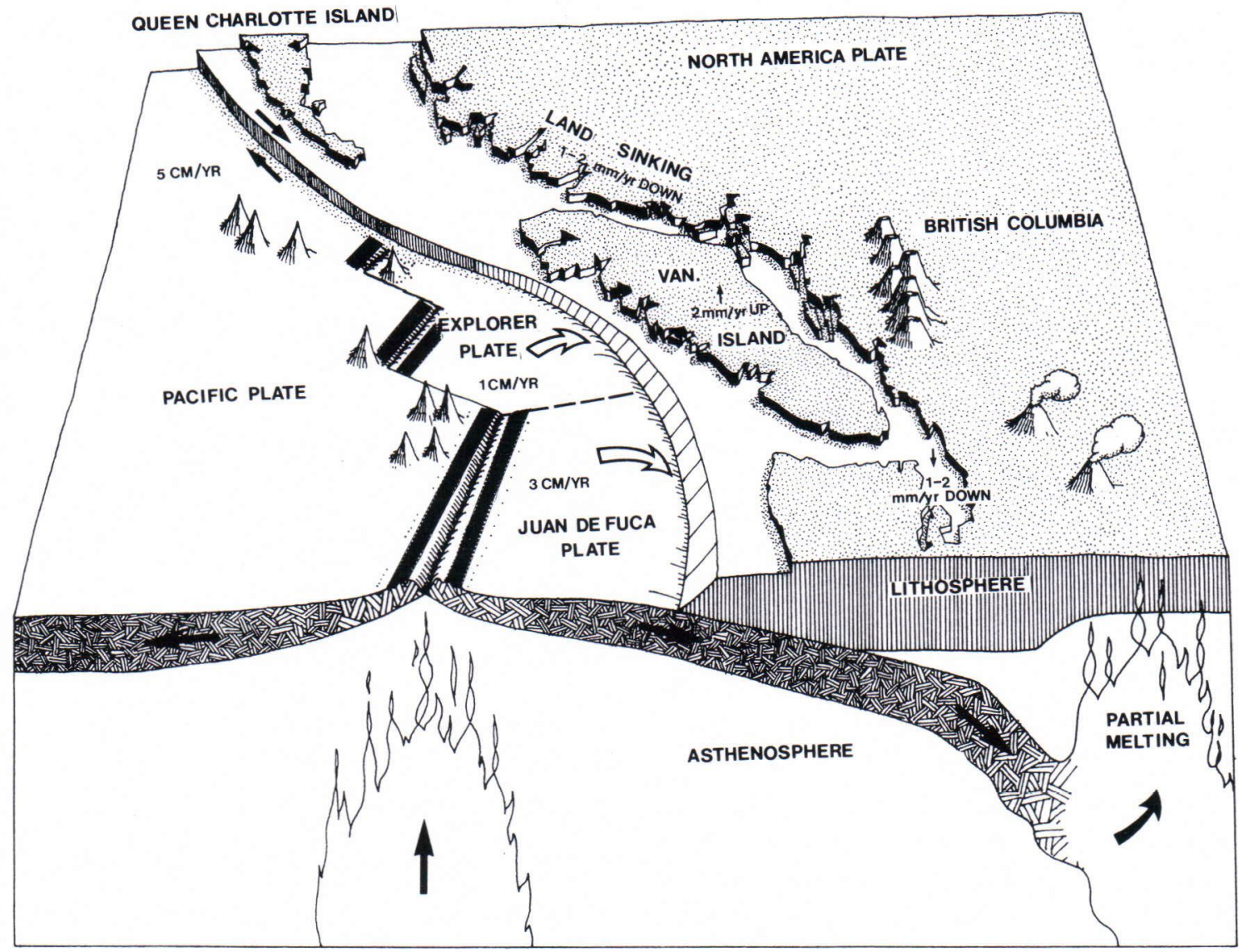

Fig. 3. Schematic diagram of plate tectonics off active west coast of Canada. Average value of horizontal or vertical rate of movement also shown (after Riddihough 1977).

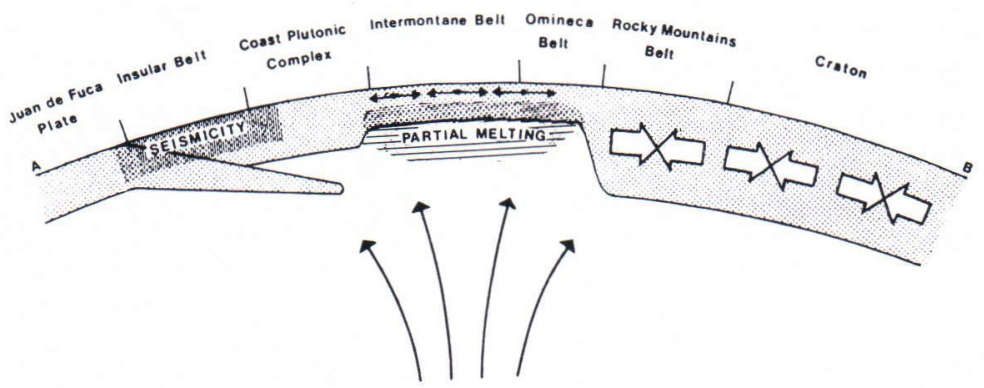

Fig. 4. Top part shows schematic diagram of vertical cross-section of Canadian Cordillera showing mantle upwelling in centre, coastal subduction on left and stress field on right. Bottom part shows location of profile, line A-B (from Gough 1986).

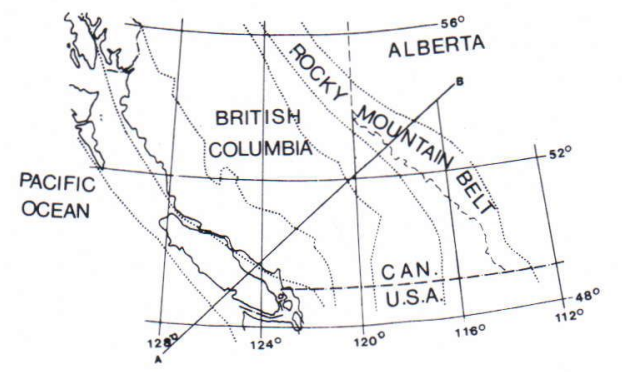



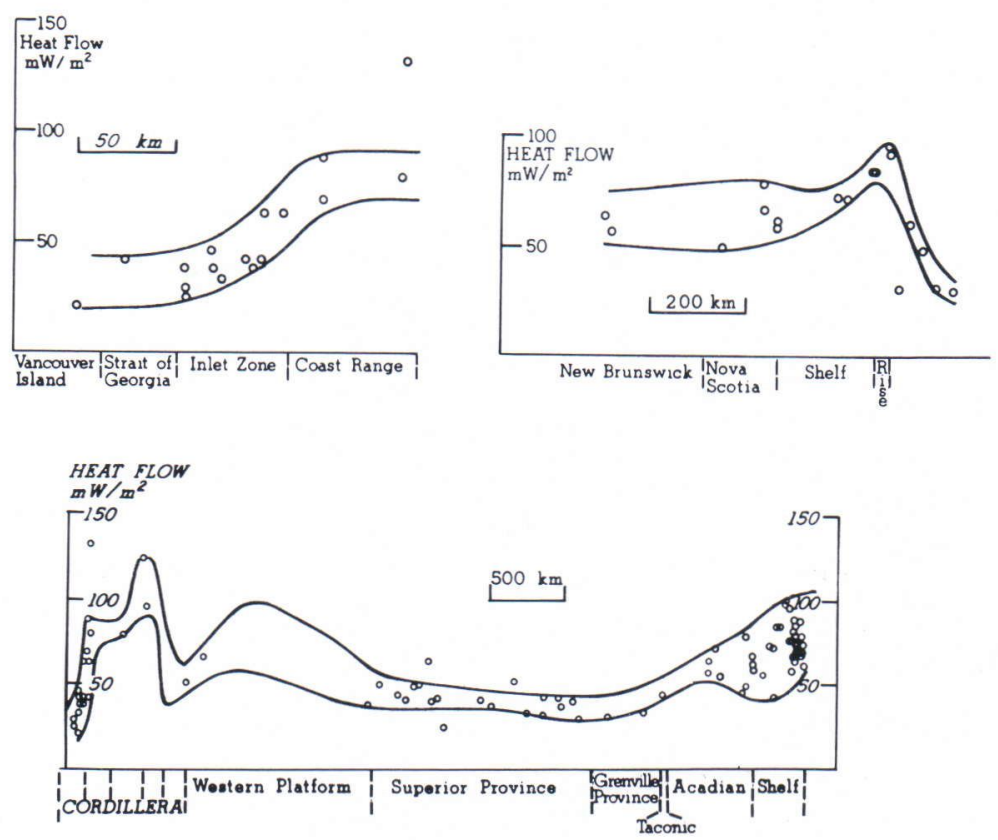

Fig. 5. Heat flow profile across southern Canada from west to east coast (bottom); detail of west and east coast regions shown in top left and top right, respectively (from Jessop et al. 1984).

Therefore mantle upwelling appears to be the major contributor to current uplift in this region. Although no fault-plane solutions have been computed for epicentres directly over the partial melt zone, a priori one would expect normal faulting. However, a fault-plane solution of a magnitude 4.8 earthquake with an epicentre on the eastern boundary of the partial melt zone indicates predominantly strike-slip faulting with a thrust component (Rogers et al. 1980, p. 1778), which likely reflects the edge effect (compression) of mantle upwelling. The b-value is close to one in this area.

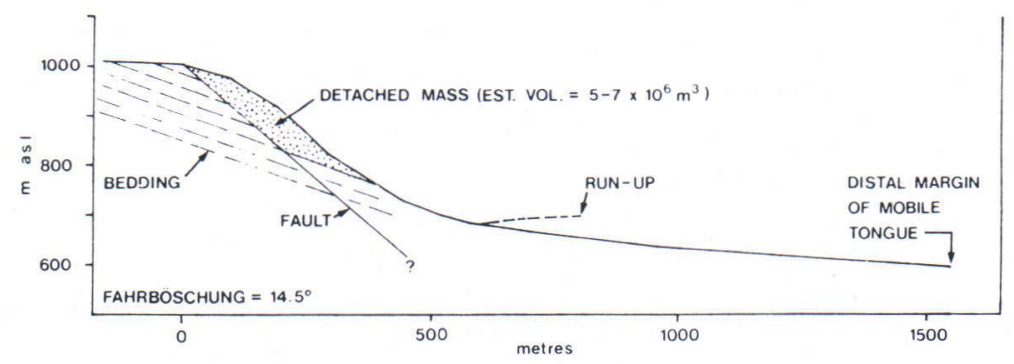

\section{Movement of mass}

\section{Rock avalanche triggered by an earthquake}

In the MacKenzie Mountains (MM in Fig. 1), an $M_{s} 6.6$ earthquake (October, 1985) triggered a rock avalanche about $10 \mathrm{~km}$ north of the epicentre. A vertical cross-section of the pre- and post-landslide topography is shown in Fig. 6. Slide initiated along the (lower) wet bedding plane and propagated upslope (Evans et al. 1987, p. 181).

Although strong ground motion records near this rock avalanche are not available for the
Fig. 6. Schematic (S-N) vertical profile of pre-landslide topography and detachment zone in MacKenzie Mountains (MM in Fig. 1). Epicentre of $\mathrm{M}$ 6.6 earthquake of October 1985 is 10 $\mathrm{km}$ to south (from Evans et al. 1987). 


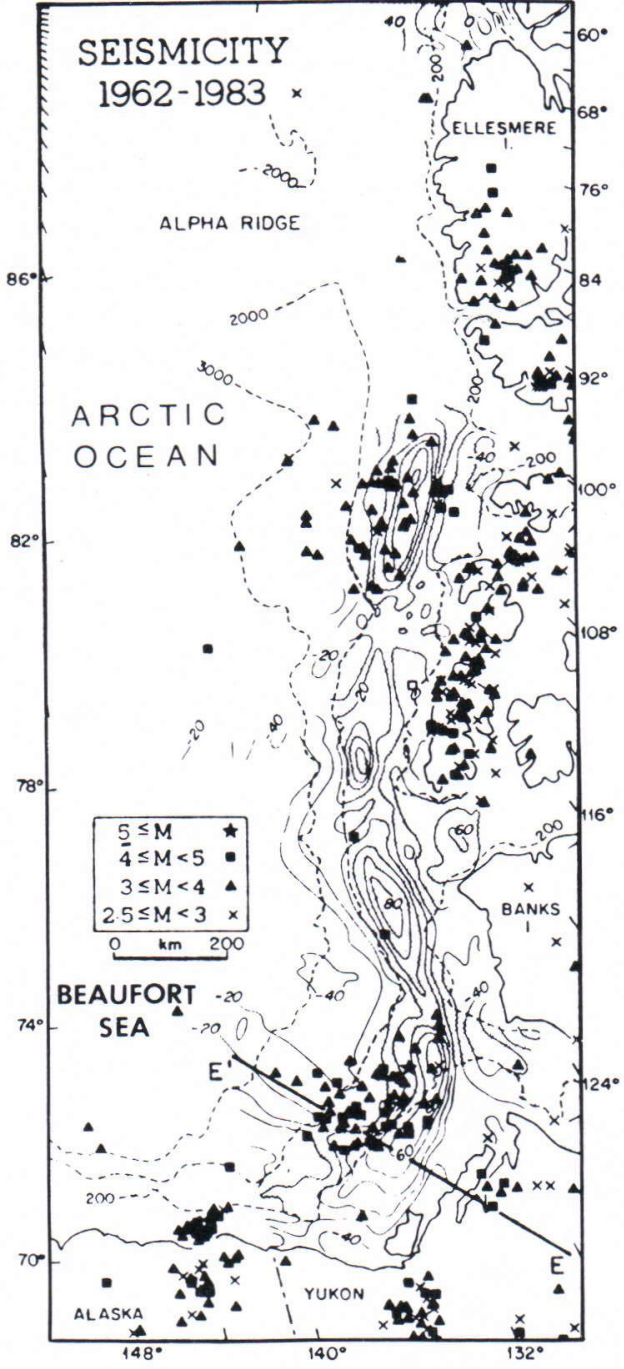

PROFILE E-E'

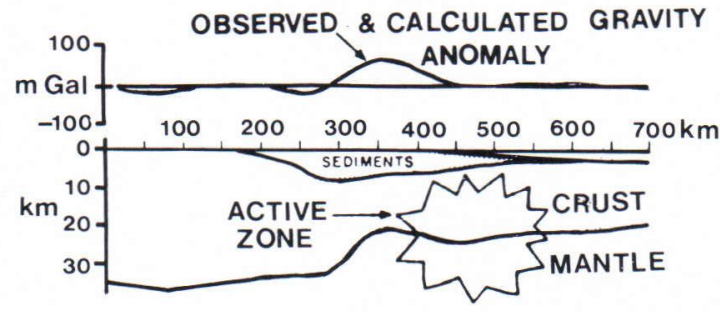

Fig. 7. Top part shows seismicity and free-air gravity anomaly contours superimposed on map of coastline of Arctic Archipelago bordering Arctic Ocean and Beaufort Sea. Bottom part shows profiles of crust-upper mantle, seismic zone and free-air gravity anomaly (after Basham et al. 1977).
October main shock, records are available for the subsequent $\left(M_{\mathrm{s}} 6.9\right.$, December 1985) large shock that originated in the same epicentral region and with a comparable source mechanism. In the vicinity of the rock avalanche, peak values of strong ground motion and associated response spectra were surprisingly high: peak ground acceleration apparently exceeded $2 \mathrm{~g}$ and peak velocity reached $50 \mathrm{~cm} / \mathrm{sec}$; velocity response spectra (5\% critical damping) exceeded $100 \mathrm{~cm} /$ sec (Weichert et al. 1986). The P-wave first arrivals likely loosened the surficial rocks and the $\mathrm{S}$-waves then triggered the main slide.

\section{Sediment loading along passive continental margins}

Along the passive margins of Canada there are certain regions where there is a chain of elliptically shaped, positive free-air gravity anomalies, some of which are seismically active. Fig. 7 shows this pattern for the Arctic coastline. The bvalue for seismic activity along the Beaufort Sea is low (less than 1.0). The seismically active offshore regions are those with faults from a previ-

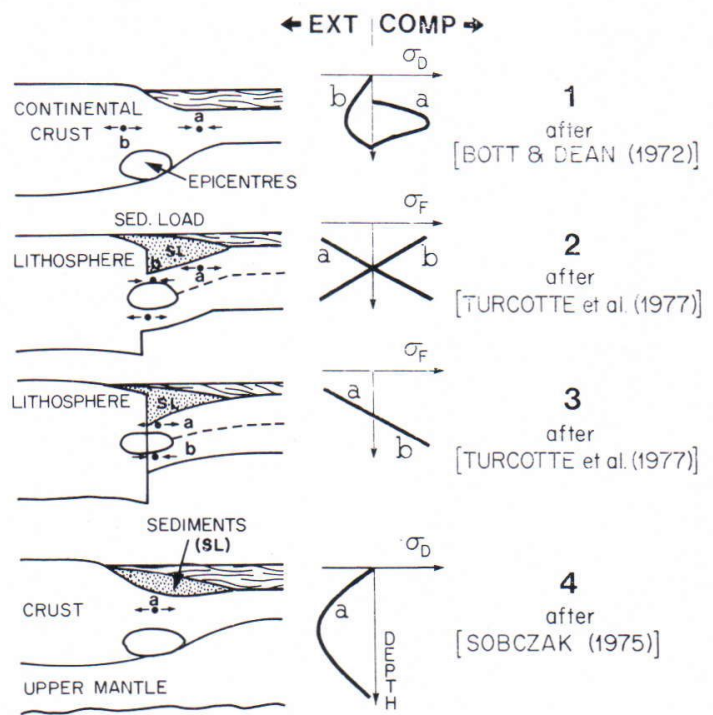

Fig. 8. Schematic profiles of four types of continent-ocean transition zones and associated deviatoric horizontal stress field. 
ous tectonic orogeny that are being reactivated by the on-going sediment loading.

Uncompensated sediment loads tend to generate deviatoric horizontal stresses normal to the trend of the coastline, as shown in Fig. 8. The preferred models generate extensional stress down to depths of at least $40 \mathrm{~km}$; evidence to support this view is an earthquake faultplane solution (Hasegawa et al. 1979, p. 822) that indicates deviatoric (horizontal) extension perpendicular to the coast line and compression parallel (approximately N-S) to the coastline. The sources of the uncompensated sediment loads along the southeast margin of the Beaufort Sea are the three main rivers that flow into this sea. Approximately $3 \times 10^{10} \mathrm{~kg}$ of solid material is deposited annually, and from the McKenzie River alone $6 \times 10^{9} \mathrm{~kg}$ of material in solution are deposited annually (Wold et al. 1970, p. 852).

Besides sediment loading, the only other known active feature under the Arctic Ocean is spreading at the mid-oceanic (Nansen-Gakkel) ridge (e.g., see Hasegawa et al. 1979, p. 817). The $\mathrm{N}-\mathrm{S}$ compressive stress regime under the Beaufort Sea is likely due to a combination of mid-oceanic spreading ridge stress and the N-S compressive stress that prevails in eastern Alaska (see Biswas et al. 1986, p. 179).

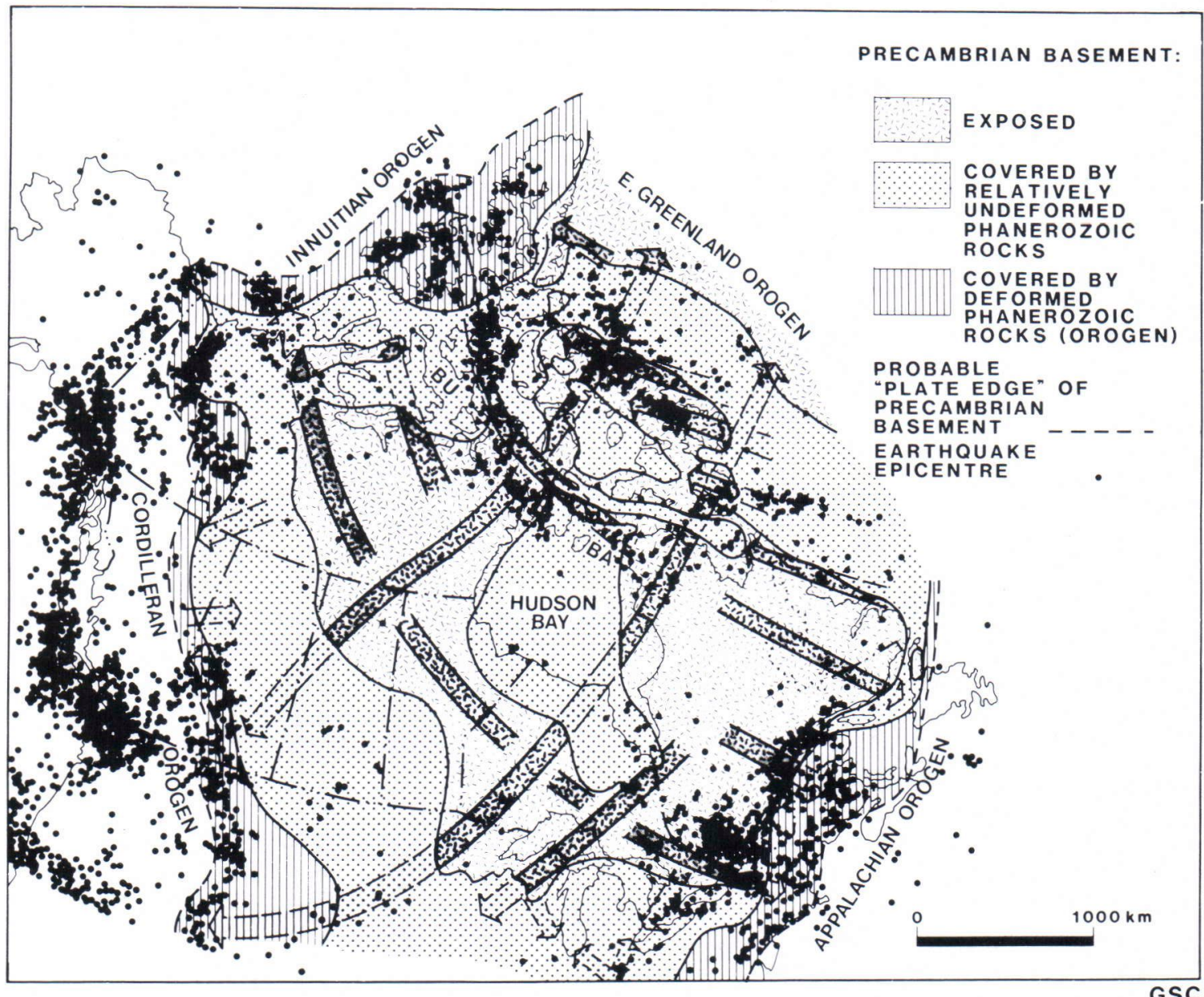

Fig. 9. Orientation of Boothia Uplift-Bell Arch (BU-BA) in relation to other positive and negative basement trends and peripheral orogenies (from Sanford et al. 1985a). 


\section{Major Submarine Landslide}

Along the continental slope in eastern Canada in the Grand Banks region (GB in Fig. 1) a massive submarine landslide occurred in 1929. This rare event severed the transatlantic cables in 28 places and generated a destructive tsunami (Doxsee 1948) that caused the loss of 27 lives and extensive property damage along the southern coast of Newfoundland, north of the submarine landslide. In-situ measures of the volume of slump is about $10^{11} \mathrm{~m}^{3}$ (Piper and Aksu 1987), with area of slumping about $37,500 \mathrm{~km}^{2}$.

There are two hypotheses concerning the source of these sediments. One view is that the source is sediments transported by the St. Lawrence River (see SLV in Fig. 1) and for this case the return period of a comparable slump is about 100,000 years (Piper and Normark 1982, p. 150). The other view is that the sediments are deposited by glaciers and for this case the return period is about 20,000 years (Piper et al. 1985, p. 20).

\section{Tectonic uplift}

The Boothia Uplift-Bell Arch (BU-BA in Fig. 1) is a prominent positive basement trend that transects the Canadian shield. The orientation of this uplift with respect to other positive and negative basement trends in the craton is shown in Fig. 9. Sanford et al. (1985a, p. 53) hypothesize that compressive stresses associated with the East Greenland and the Cordilleran orogenies subjected the intervening craton to strong NESW compression. This compression, in turn, generated a pattern of NW-SE striking uplift and subsidence basement trends. Sanford et al. suggest that the Boothia Uplift-Bell Arch likely formed by arching. However, Okulitch et al. (1986, p. 354) suggest a thrust fault mechanism, as there is evidence of up to $30 \mathrm{~km}$ of crustal shortening.

In general, horizontal tectonic stresses are insufficient to generate buckling in a moderately

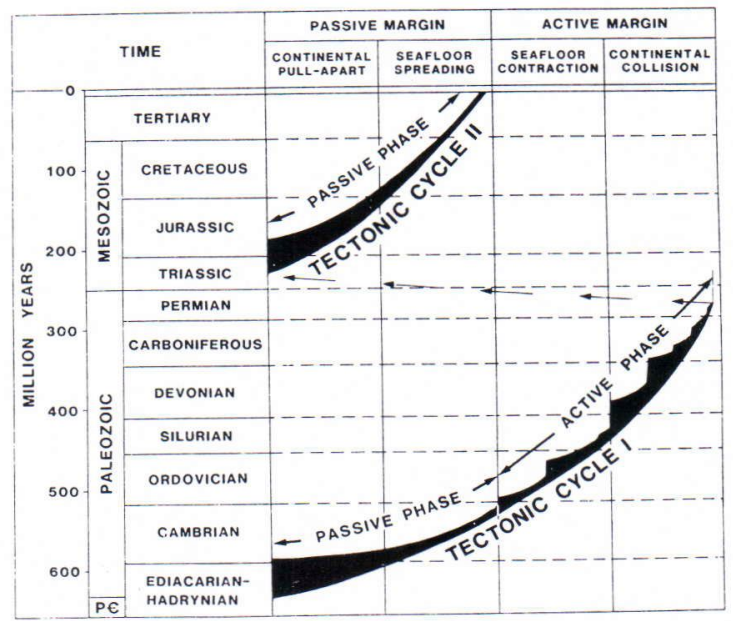

Fig. 10. Phanerozoic tectonic cycles with width of curve indicating degree of tectonism (from Sanford et al. 1985b).

uniform lithosphere (Turcotte and Schubert 1982, pp. 124-125). Fig. 10 shows that the current tectonic cycle along the northwest Atlantic is in a passive stage and near a minimum (Sanford et al. 1985b, p. 344). Thus even though stress measurements in eastern Canada indicate a high stress field in the upper crust (see Adams 1985, for stress compilation), nevertheless this stress field is not strong enough to create new tectonic features. The b-value for the BU-BA seismic trend is 0.9 .

Seismic activity along this arcuate trend was likely rejuvenated during the recent deglaciation phase. Fig. 11 shows that during the latter stages of the last deglaciation, there were ice loading centres that straddled this positive arcuate trend. As a consequence, zones of weakness along this trend were likely reactivated, thereby enhancing the seismic activity along this trend (Wetmiller and Forsyth 1982, p. 270).

\section{Steep gradients in vertical movement}

\section{Glacial isobase uplift}

Steep gradients in postglacial uplift along the northeast coast of Baffin Island, as shown in Fig. 


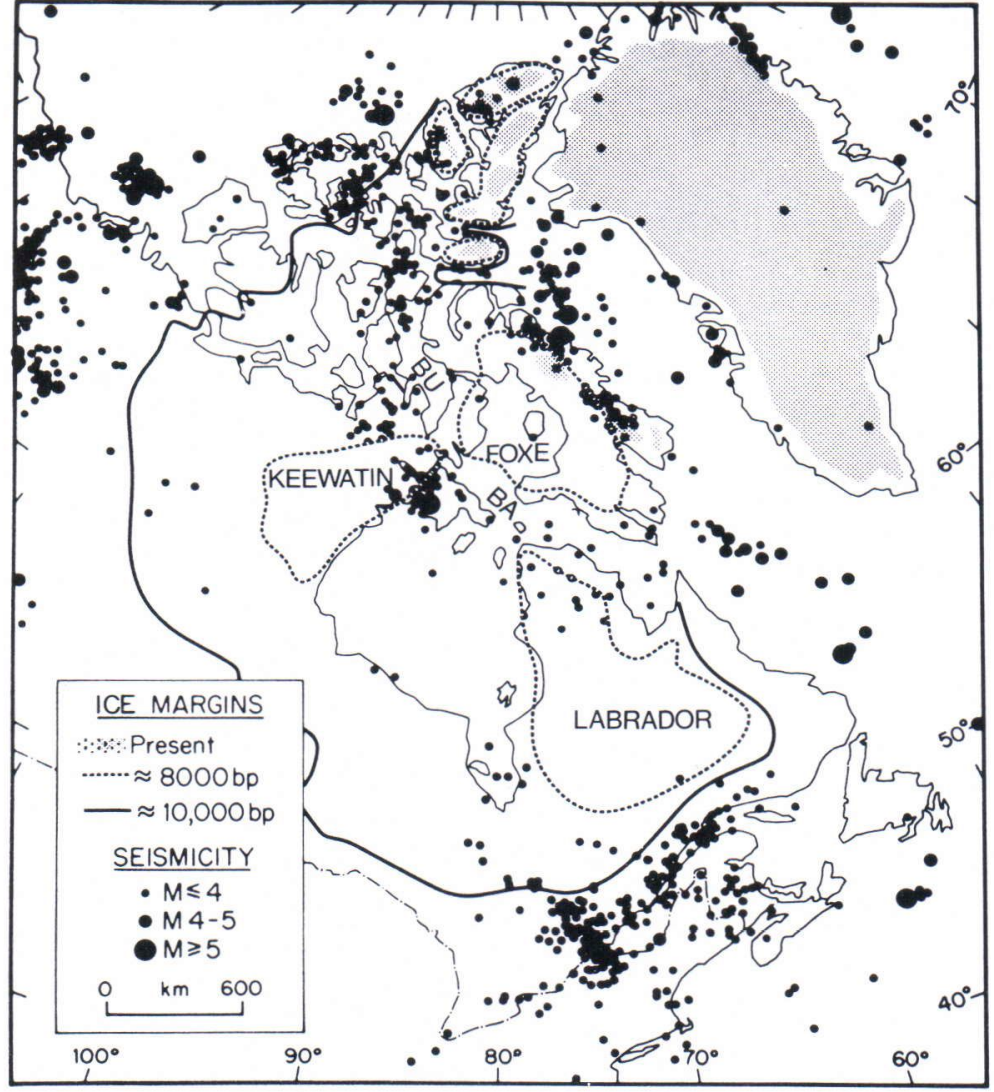

Fig. 11. Centres of ice loading in relation to Boothia Uplift-Bell Arch (BU-BA) trend and seismicity (from Wetmiller and Forsyth 1982).
12 , indicate considerable differential uplift over the past 8000 years (see Wetmiller and Forsyth 1982, p. 272). The clusters of current seismic activity in this region are probably due to a reactivation along preweakened linears by ongoing postglacial rebound; The b-value along Baffin Island is 1.1 and under Baffin Bay 0.7.

A conspicuous feature of larger magnitude earthquakes in the Baffin Island and Baffin Bay seismotectonic regimes is the prevalence of normal faulting along Baffin Island and thrust faulting under Baffin Bay. Fig. 13 displays this pattern and, in addition, three phenomena that can generate the observed stress configuration. The implicit assumption on which Fig. 13b is based is that the »neutral» stress state exists with the ice load on. Ice melting can induce fibre (longitudinal) stress in the lithosphere by flexure.
On the other hand, the induced stresses for the other two cases are due to the squeezing of continental crust towards the oceanic crust.

The stress-strain field near the periphery of an ice load depends not only on the development history of the ice load, but also on the structural heterogeneity of the crust and its response to this loading history. Thus the relative contribution of postglacial rebound stress vis-à-vis current plate tectonic stress could vary in different seismogenic regions that have undergone repeated episodes of glacial loading and unloading. For regions where the upper crust reacts more or less elastically under repeated loading-unloading cycles, the neutral stress state corresponds to the case where the ice load has melted, postglacial rebound is complete and plate tectonic stress would prevail. However, for heterogeneous, highly fractured 


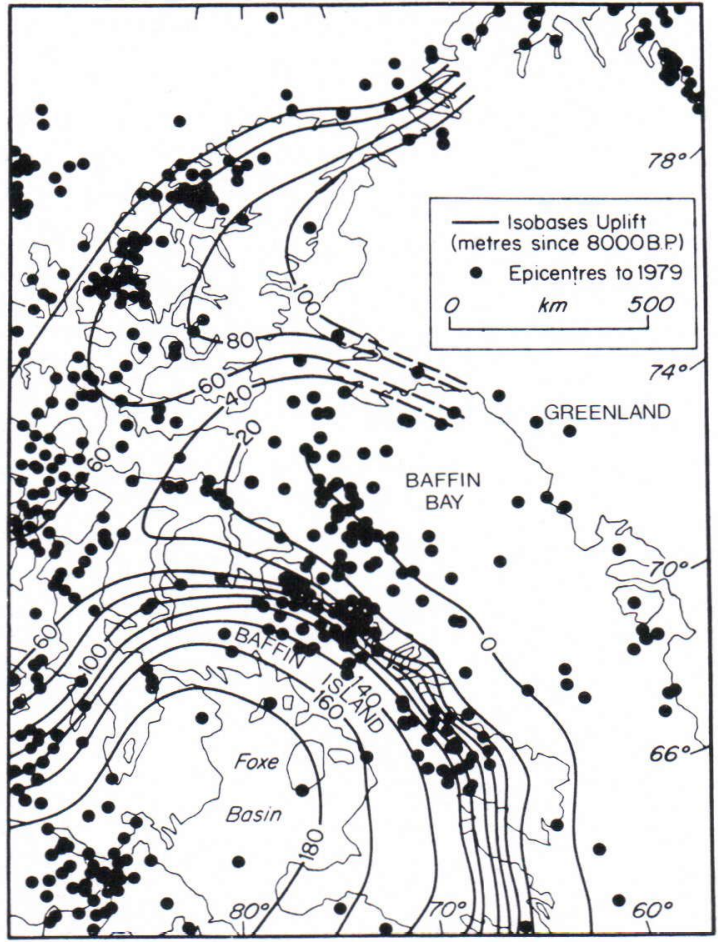

Fig. 12. Isobase postglacial uplift contours and seismicity along northeast coast of Baffin Island and adjacent regions (from Wetmiller and Forsyth 1982).

regions, induced stresses due to ice loading could dissipate through faulting, as the ice load has been on more than it has been off during the past 100,000 years (see Fig. 13b left graph and Peltier et al. 1986, p. 89). For this case, the neutral stress state would exist with the ice load on.

Several authors have assumed that the neutral stress state in the Baffin Island and Baffin Bay area exists with the ice load on. The results of Stein et al. (1979, P. 540), who consider only fibre stress (in the lithosphere) due to glacial unloading and no other (e.g. tectonic) stresses, indicate that rebound stress can dictate the mode of earthquake failure in this region. Quinlan (1984, pp. 1021-1023), who takes into account a tectonic stress component as well, concludes that rebound stress can rarely dictate the mode of earthquake failure but can act as a trigger

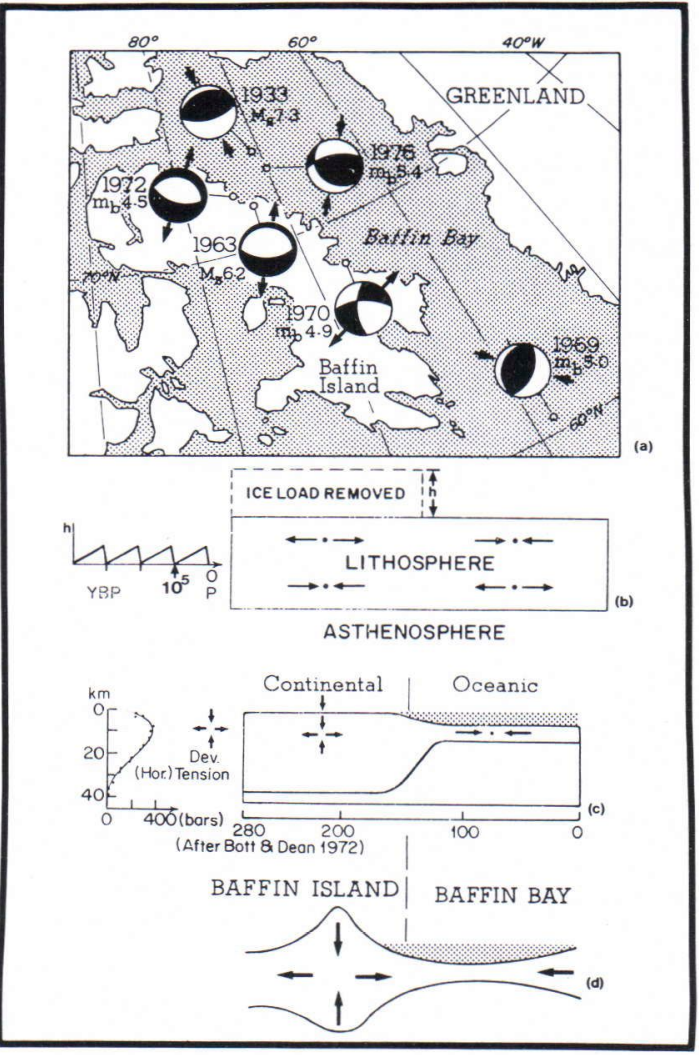

Fig. 13. Part (a) shows examples of normal faulting along Baffin Island and thrust faulting fault-plane solutions under Baffin Bay. Part (b) shows model of ice removal that can predict pattern of focal mechanisms shown in part (a) (after Stein et al. 1979) on right and ice load history on left; Laurentide ice epoch occurs at peak of ramp at $2 \times 10^{4}$ YBP (see Peltier et al. 1986). Part (c) shows how continental crust gets squeezed into oceanic crust and graph of deviatoric horizontal extension in continental crust on left (from Bott and Dean 1972). Part (d) shows how mountain topography and root can generate deviatoric extension in mountain and compression in oceanic crust (after Artyushkov 1973).

mechanism for faults that are otherwise close to failure. Sleep et al. (1988) show how rebound stress plus the inclusion of stresses due to lateral heterogeneity in the crust-upper mantle (see Fig. $13 \mathrm{c}$ and $13 \mathrm{~d}$ ) are sufficient to induce stresses in the upper crust that are large enough to generate a magnitude seven earthquake along a preweakened (relict of a rifted) zone under central Baffin Bay. 


\section{Geodetic relevelling}

In the eastern Maritimes (see region labeled M in Fig. 1) there are steep gradients in vertical uplift-rate contours. Fig. 14 shows the pattern of vertical movement based on relevelling (Vanicek 1976, p. 665). Let us consider three possible causative factors of this uplift: (1) the uplift is due to postglacial rebound for the case where the neutral stress state exists with the ice load on (cf. Baffin Island-Baffin Bay area); (2) the uplift is due to postglacial rebound but the neutral stress state exists with the ice load off; and (3) the uplift is due to other neotectonic processes. On the basis of fault-plane solutions of earthquakes in this region (the Maritimes) that indicate thrust faulting (on conjugate planes), as shown in Fig. 15 (Wetmiller et al. 1984, pp. 645-646), cases 1 and possibly 3 can be discounted because they predict a normal fault stress regime. However, since uplift rates are based on only a few observations no firm conclusions can be drawn; but it
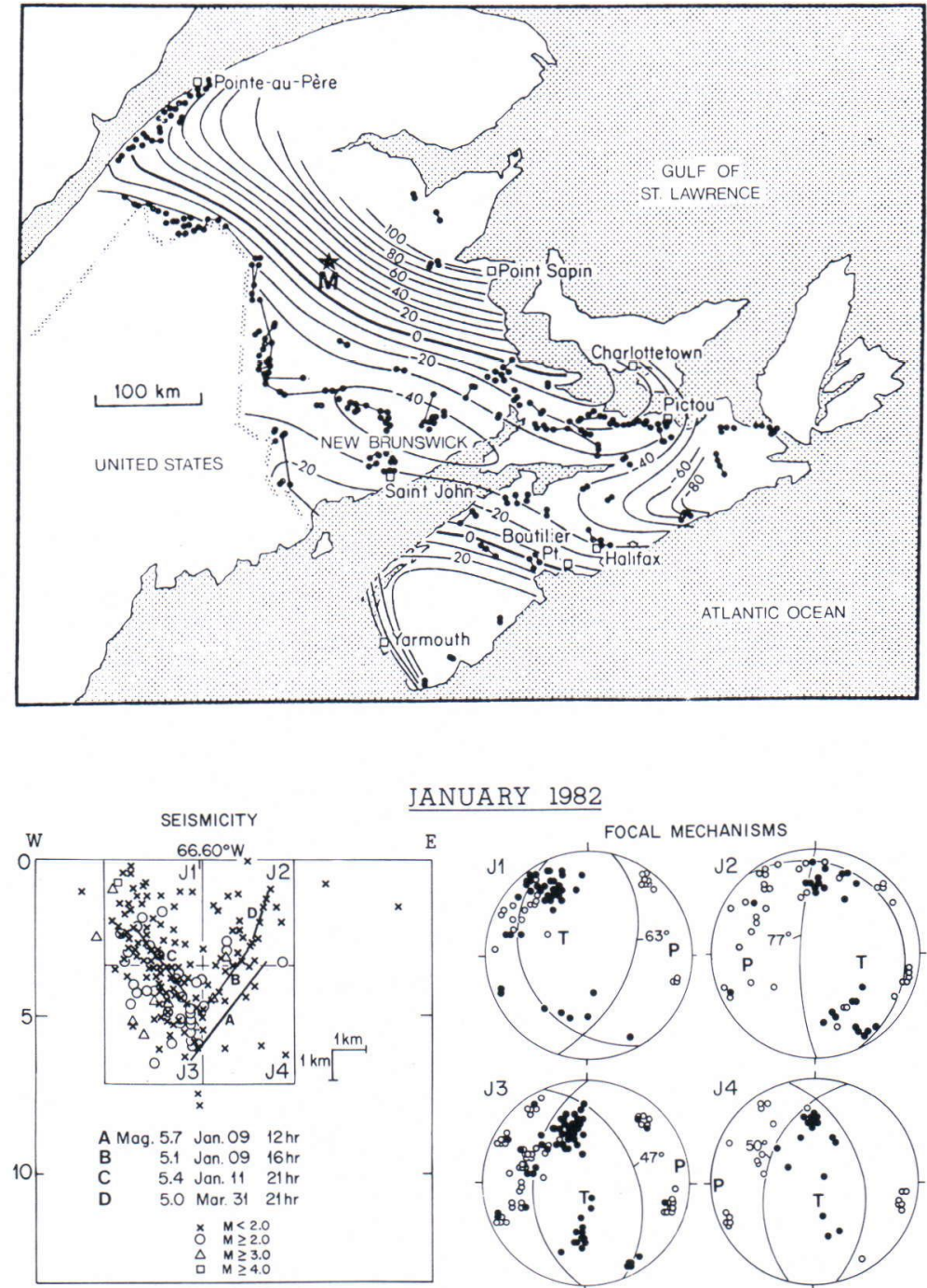

MIRAMICHI, NEW BRUNSWICK

\section{JANUARY 1982}
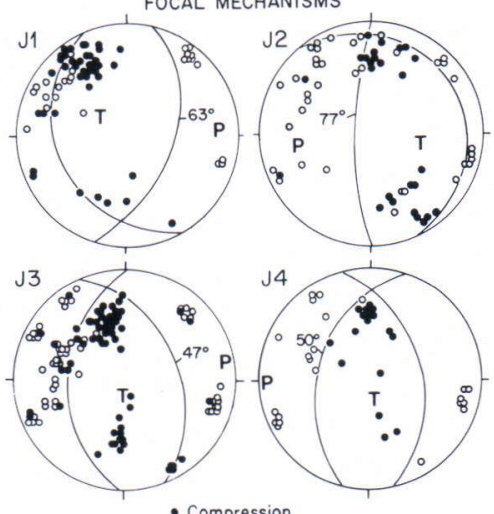

- Compression - Dilatation
Fig. 14. Pattern of vertical crustal movement in centimetres per 100 yrs in relation to epicentral region (star) of Miramichi earthquake sequence (labelled $\mathrm{M}$ in Fig. 1) (after Vanicek 1976).

Fig. 15. Composite P-nodal solutions of Miramichi earthquake aftershocks corresponding to four quadrants in figure on left, which shows projection of hypocentres onto vertical W-E profile. Solid lines A, B, C and D represent fault orientation for four main shocks. Maximum compressive stress is E-W (after Wetmiller et al. 1984). 
would appear that plate tectonic stress prevails. The heat flow is moderately high as compared with the Canadian Shield to the east (see Fig. 5) and earthquake foci tend to be shallower than for the shield (Hasegawa 1986, p. 89).

\section{Block boundaries and movement}

From satellite imagery and seismic patterns along the St. Lawrence Valley (SLV in Fig. 1) and the Ottawa Valley, Sanford et al. (1984, p. 93) delineate observed and assumed block boundaries as shown in Fig. 16. Sanford et al. hypothesize that a reactivation of seismically active blocks by block tilting and rotation due to underlying viscoelastic processes could be the source of the observed seismic clusters. This hypothesis is in agreement with Zoback and Zoback (1986, p. 13) who state that an upwards migration of stress and strain is required to account for some eastern United States earthquakes.

More relevelling data are required in this region to test this hypothesis. Also the presence of individual block movement raises the question as to why earthquake hypocentres do not cluster around the observed and hypothesized block boundaries.

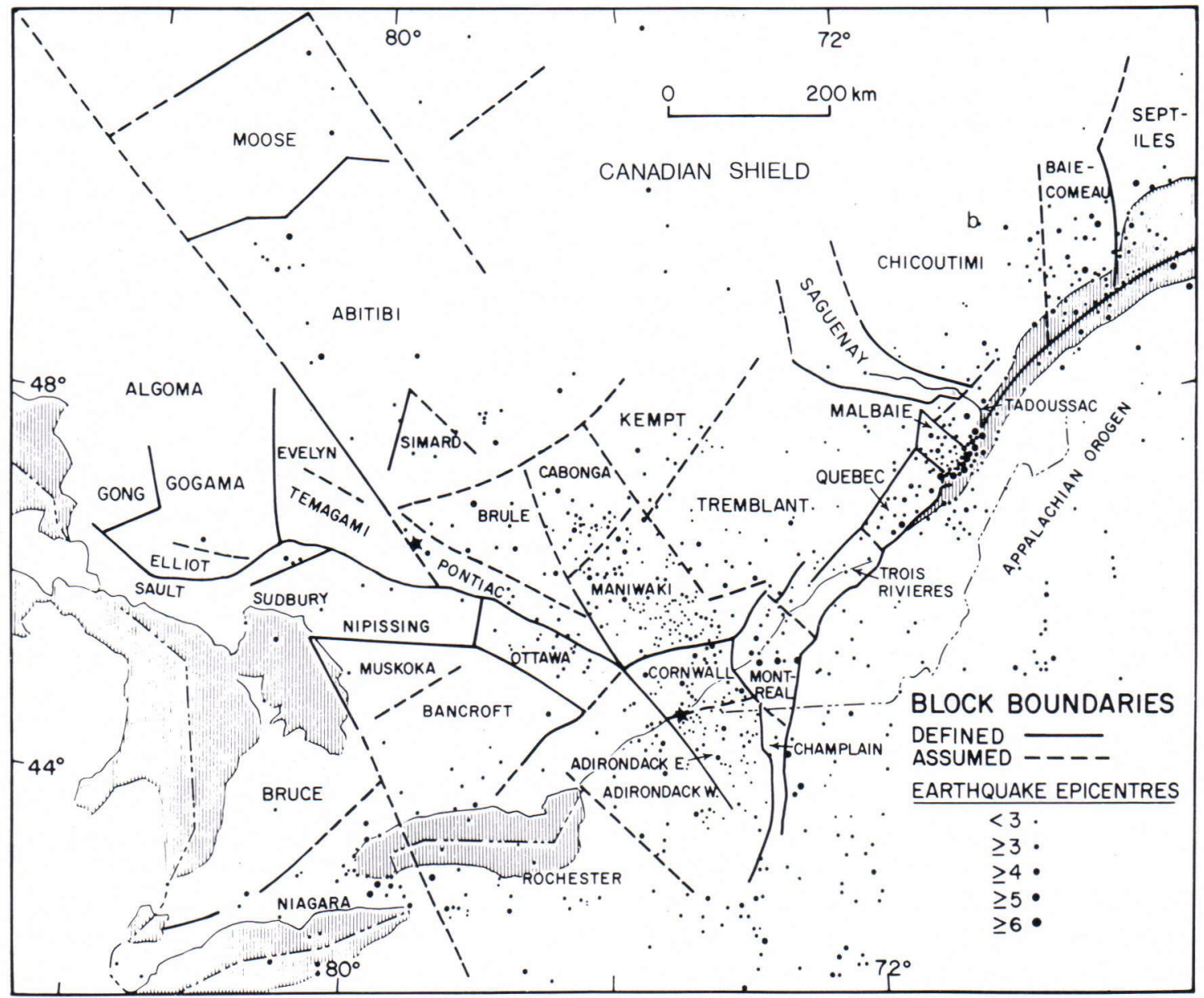

Fig. 16. Major fracture systems and fault blocks along St. Lawrence Valley (SLV in Fig. 1) and along Ottawa-Bonnechere graben (from Sanford et al. 1984). 


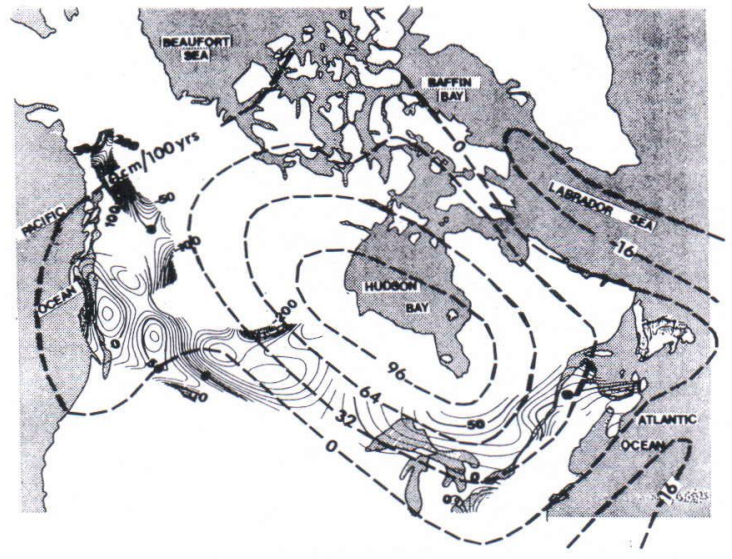

Fig. 17. Vertical rate of movement contours from relevelling data in $\mathrm{cm}$ per 100 yrs shown as solid lines (from Vanicek and Nagy 1980) and current postglacial uplift rate in dashed lines (from Peltier 1986) superimposed on outline of Canada.

\section{Postglacial rebound (Hudson Bay Region)}

Fig. 17 shows calculated current deglaciation induced (»deglacial») emergence rate (Peltier 1986, p. 9115) superimposed on observed total emergence rate (Vanicek and Nagy 1980, p. 38). Comparable rates of postglacial uplift in the central part of the craton (Canadian Shield) have been derived by Andrews (1970a, p. 713).

The correlation between postglacial rebound and relevelled contours is good on the craton but there are pronounced differences along the west and east coasts of Canada. The close correlations south and southeast of Hudson Bay imply that vertical movement in these areas of the craton are controlled predominantly by postglacial rebound. Southwest of Hudson Bay, along the southwest coast of British Columbia, plate subduction is the controlling factor and further inland, probably mantle upwelling. There is some doubt as to the validity of the pronounced subsidence rate indicated southwest of Hudson Bay (on the Western Canada Sedimentary Basin) and the pronounced uplift along the east coast because of the scarcity of data. The steep gradients to the northwest are likely due to plate tectonic interactions, transform motion and subduction.
Thus the centre of the craton (Hudson Bay area) is rising at a mean rate of $10 \mathrm{~mm} /$ year or $100 \mathrm{~cm} /$ 100 yrs. However, a re-examination and re-interpretation of tide gauge data at Churchill (on west side of Hudson Bay) by Barnett (1966, p. 85 ) indicated an uplift rate of $73 \mathrm{~cm} / 100 \mathrm{yrs}$. But a re-evaluation of this data by Barnett (1970, p. 626) indicates an uplift rate of only $39 \mathrm{~cm} /$ 100 yrs.

\section{Remaining uplift around Hudson Bay}

Accurate estimates of remaining (postglacial) uplift are inherently difficult, as they depend on a number of factors (Andrews 1970b, p. 132). Some of the more important parameters are as follows: a detailed configuration of the viscosity and density variations versus depth for the asthenosphere; the thickness and effective flexural rigidity of the lithosphere; the spatio-temporal pattern of relative-sea-level, which reflects the combined effects of geoidal and eustatic changes; previous ice loading history (e.g. see Peltier 1985, p. 587; Peltier et al. 1986, p. 89; Wolf 1986a, p. 46). Other factors that could complicate the issue are nonlinear effects such as faulting, block tilting and rotation.

The spread in calculations of remaining postglacial uplift for different mantle rheologies is shown in Fig. 18. The physical parameters for the three models are held fixed except for the variation of viscosity with depth. Model L1 has a uniform viscosity of $10^{21} \mathrm{~Pa} \mathrm{~s}, \mathrm{~L} 2$ a viscosity of $10^{22} \mathrm{~Pa} \mathrm{~s}$ below the $670 \mathrm{~km}$ discontinuity and L3 is similar to L2 except that L3 has a low viscosity of $10^{19} \mathrm{~Pa} \mathrm{~s}$ in the top $100 \mathrm{~km}$ of the asthenosphere. All three models have density jumps in the mantle associated with the phase transitions at 420 and $670 \mathrm{~km}$ depth (Peltier and Wu 1982, p. 734). Corresponding estimates of remaining uplift in the Hudson Bay region vary by a factor of three.

Remaining uplift $\left(\mathrm{w}_{\mathrm{r}}\right)$ can be calculated from parameters such as relaxation time $\left(\tau_{r}\right)$, free 


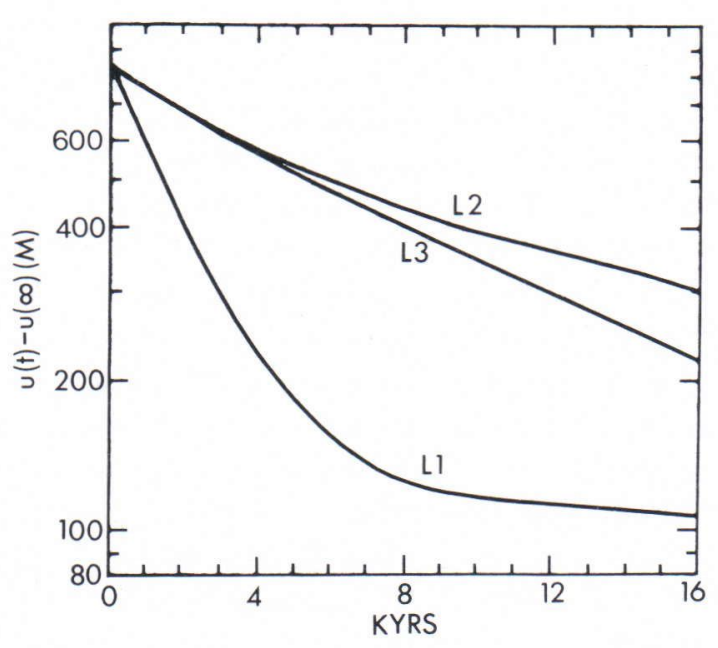

Fig. 18. Relative vertical displacement for Hudson Bay area over past 16,000 yrs for models L1, L2 and L3, which are described in text (from Peltier and Wu, 1982).

air gravity anomaly $\left(\Delta \mathrm{g}_{\mathrm{fa}}\right)$ and geoid anomaly $\left(\mathrm{w}_{\mathrm{GEOID}}\right)$. However, a priori, the corresponding results could be strongly model dependent. For a uniform half-space with a Newtonian viscosity, remaining uplift, as based on a single relaxation time, is given by (Turcotte and Schubert 1982, p. 247)

$w_{r}=w_{o} e^{-t / \tau_{r}}$ where $\mathrm{w}_{\mathrm{o}}$ is the depression in the central (in the present case the Hudson Bay area) part just after the Laurentide ice has completely melted, which is taken as time $t=0$ and $\tau_{r}=4 \pi \mu /(\rho g \lambda)$ where $\mu$ is viscosity, $\rho$ is mean density of the upper mantle, $g$ is the acceleration due to gravity and $\lambda$ is wavelength of the anomaly. Walcott (1970, p. 719) and also Peltier and Wu (1982, p. 734) consider two relaxation times. The free-air gravity anomaly $\left(\Delta \mathrm{g}_{\mathrm{fa}}\right)$ is related to $\mathrm{w}_{\mathrm{r}}$ by (cf. Turcotte and Schubert 1982, p. 221)

$$
\Delta \mathrm{g}_{\mathrm{fa}}(\lambda)=2 \pi \rho_{\mathrm{c}} \mathrm{G} \cdot \mathrm{w}_{\mathrm{r}}(\lambda) \cdot \cos \frac{2 \pi \mathrm{x}}{\lambda}
$$

where $\rho_{c}$ is density of the crust, G is the gravitational constant, $\lambda$ is the wavelength of the assumed sinusoidal anomaly and $\mathrm{x}$ is the horizontal-radial distance from the centre of Hudson Bay. Remaining uplift is related to geoid anomaly $\left(\mathrm{w}_{\mathrm{GEOID}}\right)$ by (D. Wolf, written communication 1987)

$\mathrm{w}_{\mathrm{GEOID}}(\lambda)=\frac{\rho_{\mathrm{c}} \mathrm{G}}{\mathrm{g}} \cdot \lambda \cdot \mathrm{w}_{\mathrm{r}}(\lambda) \cdot \cos \frac{2 \pi \mathrm{x}}{\lambda}$

where the parameters are as defined previously. The exponential depth-dependent term, $\exp (2 \pi \mathrm{z} /$ $\lambda$ ), where $z$ is depth, is not shown in eqs. (2) and

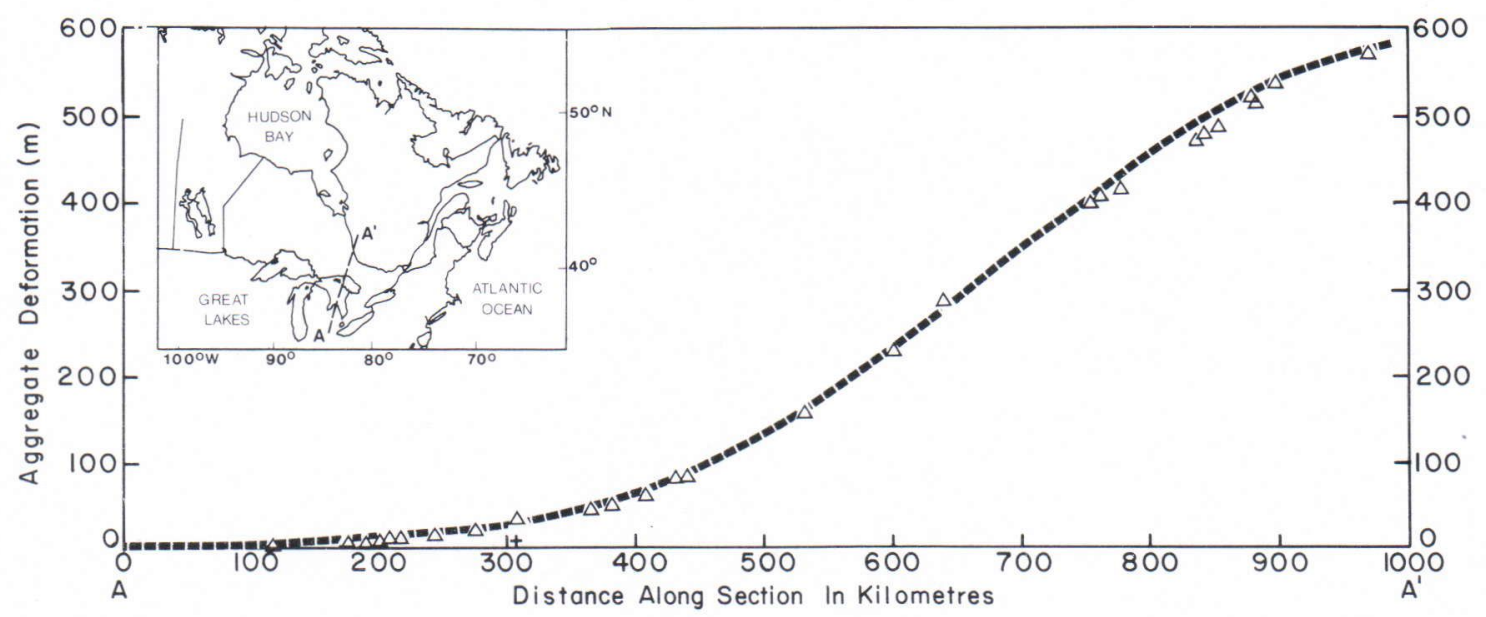

Fig. 19. Aggregate deformation (uplift) of point A' relative to point A (see inset) due to most recent (Laurentide) deglaciation (from Bowlby 1987). 


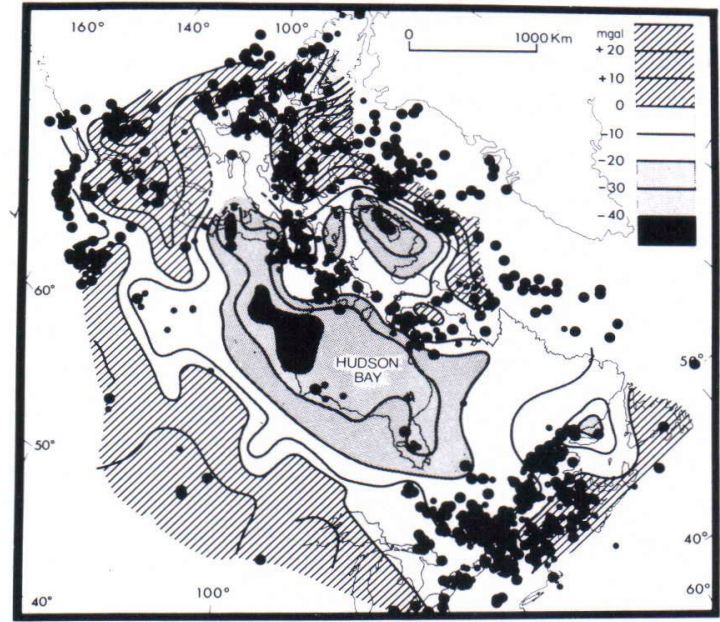

Fig. 20. Smoothed free-air gravity anomaly map of Hudson Bay and peripheral region (from Walcott 1972) and seismicity (see Forsyth 1981).

(3) because this term equals unity at the free surface $(z=0)$.

Estimates of remaining uplift in the Hudson Bay area, as based on eqs. (1), (2) and (3), are either inherently difficult or indicate disparate values. A reliable estimate of $\mathrm{w}_{\mathrm{o}}$ in eq. (1) is difficult because this estimate depends on the ice load history (cf. Clark 1980, p. 4320; Peltier et al. 1978, p. 94), in particular the maximum ice thickness, the corresponding maximum ground depression, which is approximately one-third of the maximum ice thickness for long wavelengths, and the rebound during ice melting (i.e. proglacial rebound). In addition there are several dominant relaxation times, of the order of $2 \times 10^{3}$ yrs and $10^{5}$ yrs (Peltier and Wu 1982, p. 734). The aggregate uplift curve, which includes both proglacial and postglacial uplift, in Fig. 19 indicates a lower limit of about $600 \mathrm{~m}$ for the maximum ground depression under Hudson Bay during the most recent (Laurentide) ice age (Bowlby 1987). From the free-air gravity anomaly pattern shown in Fig. 20 (Walcott, 1972, p. 877), the peak in the gravity anomaly is $-40 \mathrm{mGals}$ but the average over Hudson Bay is closer to - 30 mGals. For these two cases, remaining uplift $\left(\mathrm{w}_{\mathrm{r}}\right)$ as based on eq. (2) is $350 \mathrm{~m}$ and $250 \mathrm{~m}$, respectively. From the geoid anomaly shown in Fig. 21 (Vanicek and Nagy 1981, p. 84), the peak depression is $60 \mathrm{~m}$ but the average over the Hudson Bay area is closer to $50 \mathrm{~m}$. Fig. 22 shows, for an essentially uniform earth model and a maximum ice thickness of $4 \mathrm{~km}$, the relation between geoid anomaly and remaining uplift for distances (x) from the centre of Hudson Bay ranging from $1400 \mathrm{~km}$ to $2000 \mathrm{~km}$ (Wolf 1986b, p. 271). Eq. (3) can be used to estimate the corresponding value for the central part of Hudson Bay. For the Laurentide ice sheet, for which the wave-

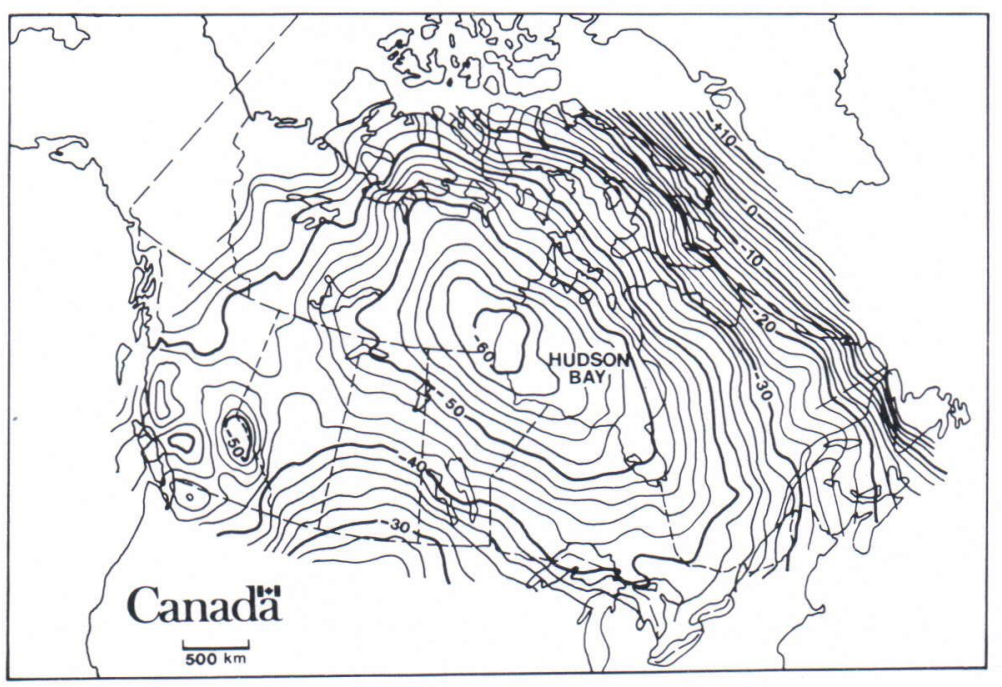

Fig. 21. Gravimetric geoid contours (metres) in Hudson Bay area and surroundings relative to Geodetic Reference System 1967 (from Vanicek and Nagy 1981). 

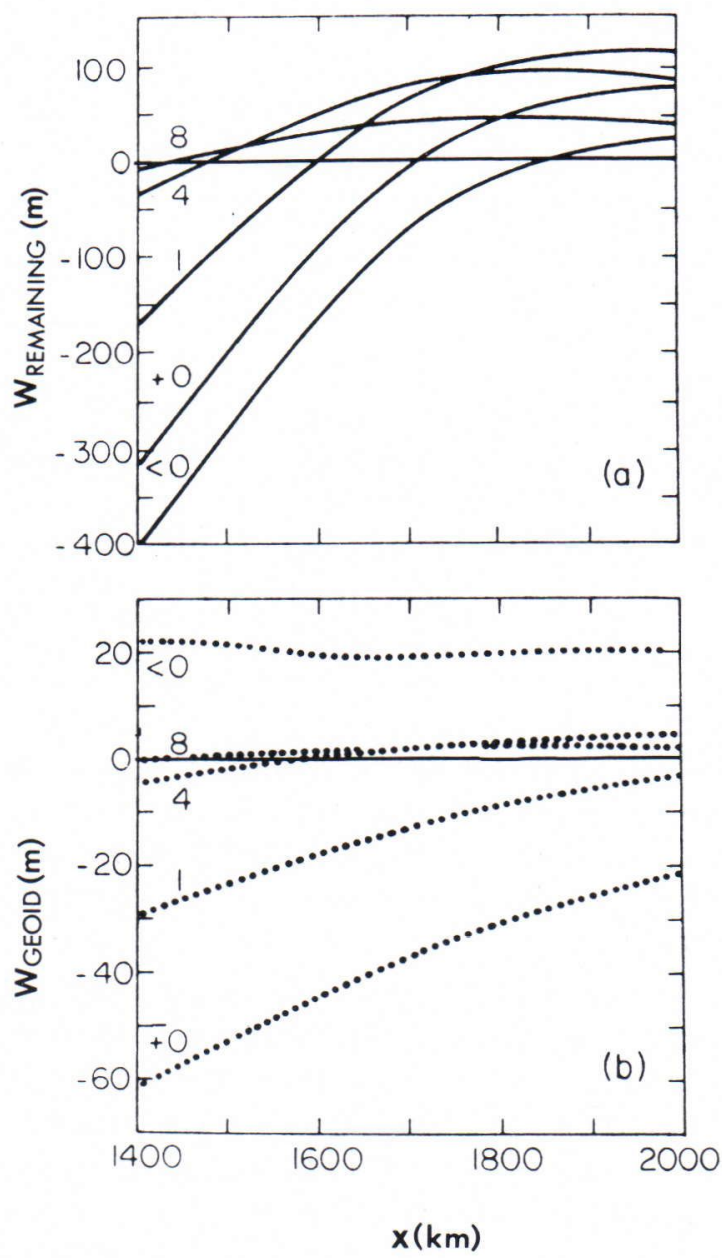

Fig. 22. Part (a) shows surface displacement, $w_{\text {remaining }}$ and part (b) corresponding geoid displacement, $w_{\mathrm{GEOID}}$, as function of radial-horizontal distance $(\mathrm{x})$ from centre of Hudson Bay for discrete times (Kyrs) since ice load removal (from Wolf 1986b).

length $(\lambda)$ is taken to be $6000 \mathrm{~km}$, from eq. (3) $\mathrm{w}_{\mathrm{r}}=\mathrm{w}_{\mathrm{GEOID}} / 1.2 \times 10^{-1} \mathrm{~m}$. For the peak and average value of the geoid depression in the Hudson Bay area, the corresponding values of $\mathrm{w}_{\mathrm{r}}$ are $500 \mathrm{~m}$ and $400 \mathrm{~m}$, respectively. The revised uplift rate of $40 \mathrm{~cm} / 100$ yrs at Churchill by Barnett (1970, p. 626) vis-à-vis the rate of $100 \mathrm{~cm} /$ 100 yrs indicated in Fig. 17, implies that most of the postglacial rebound may have taken place so that the remaining postglacial uplift is much less than the above estimates, and could be of the order of $100 \mathrm{~m}$ or less. Thus estimates of remaining postglacial uplift vary by about a factor of four (cf. Andrews 1970b, p. 132; Peltier and Wu 1982, p. 734).

\section{Postglacial faults}

Fig. 23 shows postglacial faults in eastern Canada as compiled by Adams (1981, p. 27). Postglacial faults are generally observed where glaciers have smoothed and striated bedrock. In general the observed faults have minute throws (a few tens of mm or less) and are only detected because the surfaces they displace are smooth. Although individual fault throws are small, they are systematic and could cumulate to significant displacement (1 to $2 \mathrm{~m}$ ) if faulting were as widespread beneath surficial cover as it appears to be on outcrops.

The relative offsets of the glaciated surfaces occur on bedding planes, cleavages or joints or other high-angle, pre-existing planes of weakness. The normal to the strike of the faults points towards Hudson bay, with a mean in the N-S direction, as shown by the inset in Fig. 23. Thus the orientation of these faults is consistent with the direction in which the ice retreated. The faults are roughly parallel $\left( \pm 20^{\circ}\right)$ to the ice margins (see Prest 1970, pp. 714-725). The ambient neotectonic stress field lies in the NE-SW quadrant with a mean in the NE-SW direction (Hasegawa et al. 1985, p. 3640).

The depth to which postglacial faults extend is uncertain (see Adams 1981, p. 10). One way to estimate the depth of postglacial faulting from surface measurements near a fault is shown in Fig. 24. The fault model is shown at the top and consists of a rectangular, vertical fault of length $\mathrm{L}$, width $\mathrm{W}$, and relative offset $\mathrm{D}$ (held fixed at $1 \mathrm{~cm}$ in Fig. 24) at the free surface. Vertical ground displacement $\mathrm{U}_{3}$ (negative sign is uplift) and tilt $\frac{\partial}{\partial \mathrm{x}_{2}}\left(-\mathrm{U}_{3}\right)$ are shown at distances from the fault of up to $1 \mathrm{~km}$. The graphs are drawn 


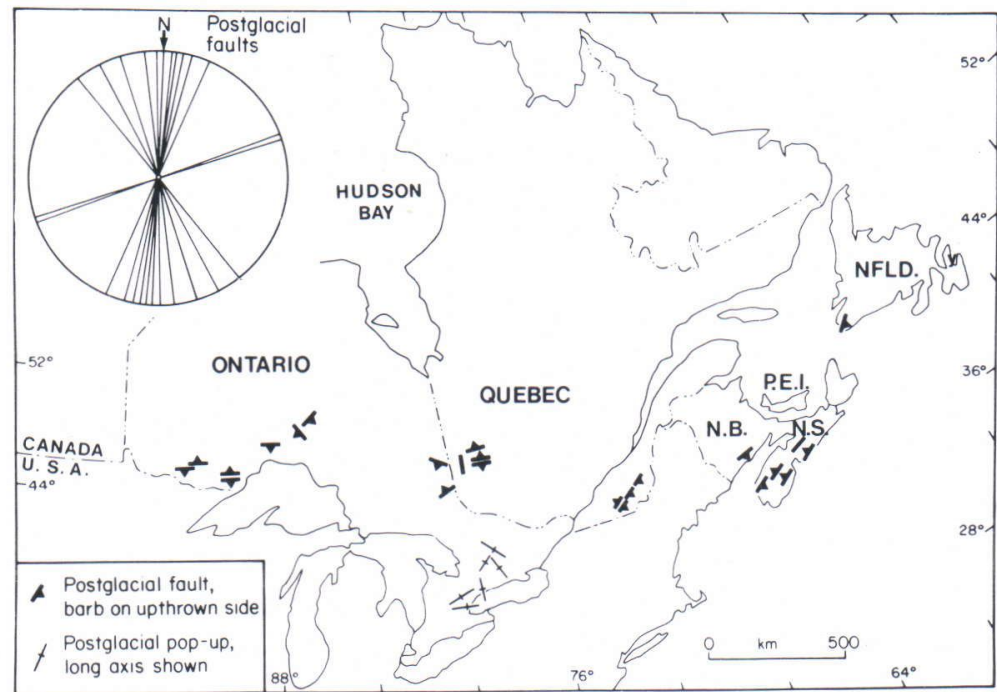

Fig. 23. Postglacial faulting and related features in eastern Canada. Top left shows orientation of stress field inferred from faults (from Adams 1981).
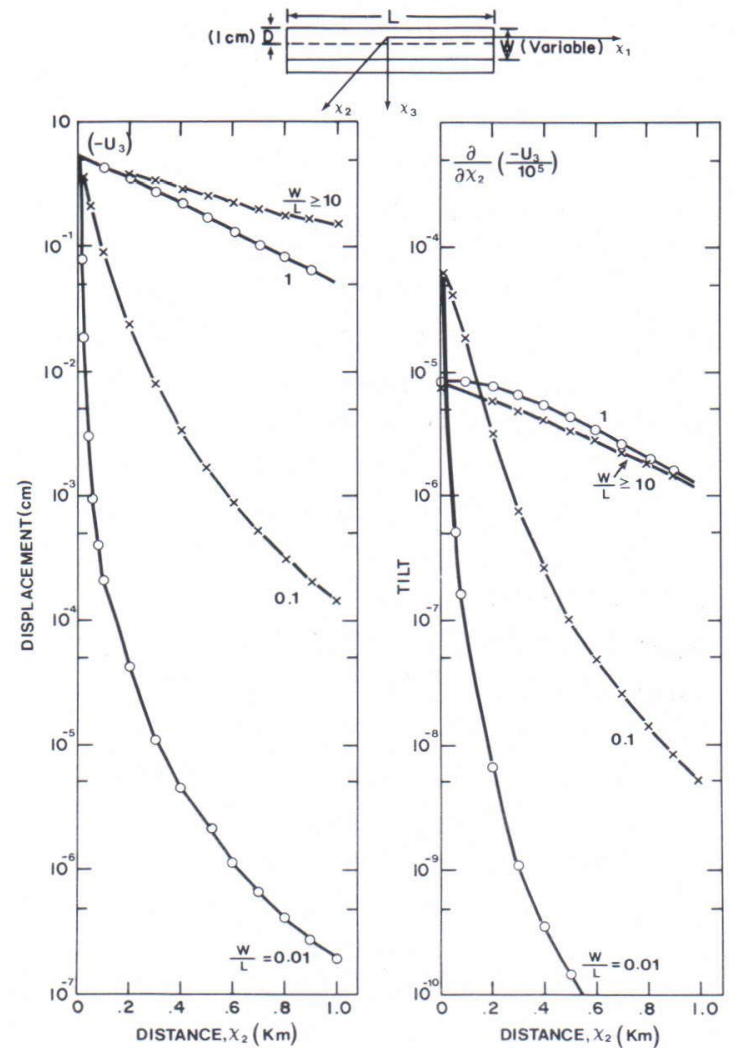

Fig. 24. Ground surface displacement and tilt versus distance $\left(x_{2}\right)$ from (postglacial) fault (top figure) for unit vertical offset $\left(D_{3}=1 \mathrm{~cm}\right)$ and different aspect ratios, W/L, where $\mathrm{L}$ is fault length and $\mathrm{W}$, fault width or equivalently depth of vertical fault, in homogeneous half space. for aspect ratios $(\mathrm{W} / \mathrm{L})$ varying from 0.01 to greater than 10. For any arbitrary displacement (D), the curves can be scaled by simply multiplying by D (cm) (formulation of Press 1965, p. 2398).

Fig. 24 can be used to estimate the depth of postglacial faults provided certain conditions are satisfied. The terrain must not be too irregular so that undulations and mean slope can be removed. There must not be a thick surficial layer of unconsolidated sediments that could be loosely coupled to the underlying bedrock. Then, provided fault length and dislocation are measurable, the aspect ratio and thence fault width (depth) can be read from Fig. 24. In general, the greater the distance from the fault that the effects (displacement and tilt) of the postglacial fault can be detected, the deeper the fault.

\section{Postglacial rebound in Canada and Fennoscandia}

Large scale (long wavelength) features of postglacial rebound in Canada and Fennoscandia can be modeled by an elastic-viscoelastic model of the lithosphere and asthenosphere (Peltier and Wu 1982, p. 732; Peltier 1986, p. 9115). Fig. 25 shows the ice configuration at the height of the 
Fig. 25. Maximum extent of ice sheet 18,000 years ago over Canada and Fennoscandia, with peak ice thickness in metres (from Covey 1984).

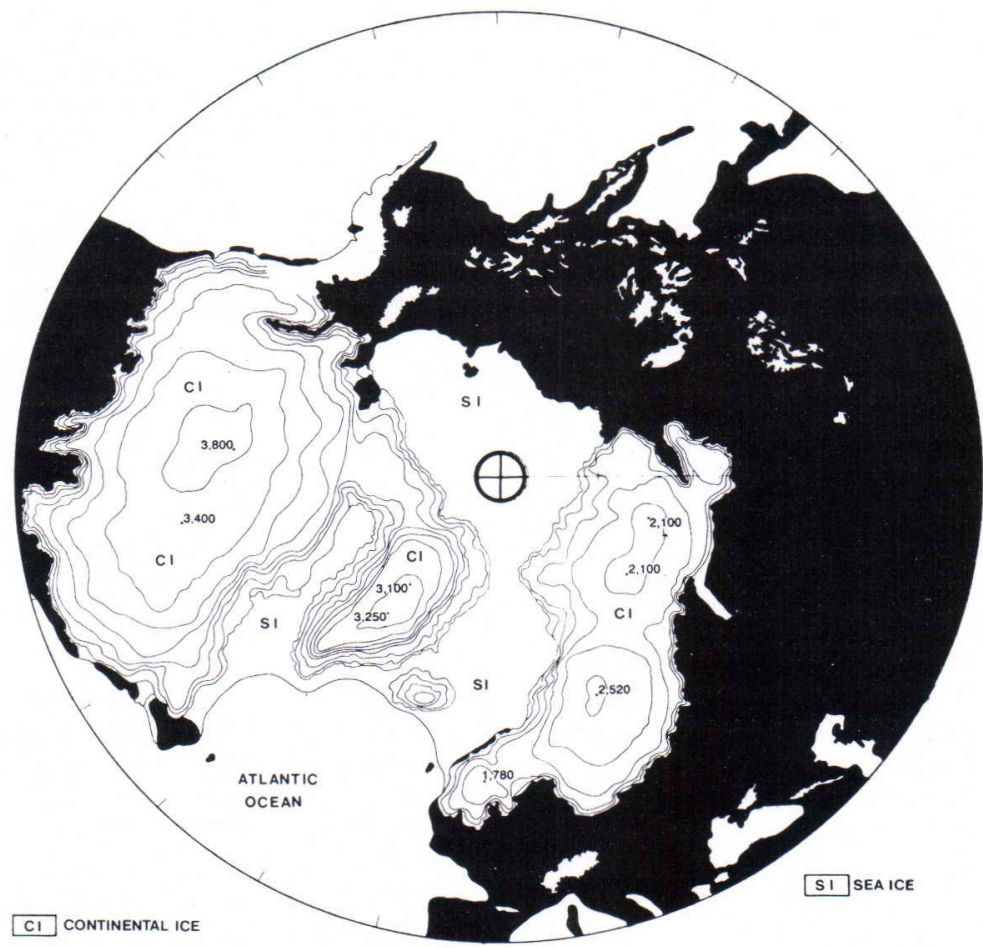

most recent ice age $(18,000$ years ago $)$ and the only difference in the configuration in Canada and Fennoscandia is in scale, not in shape. Long wavelength features do not »see» local structural features such as weakened faults and tilted blocks, which have much shorter wavelengths. The response of these local heterogeneous features to postglacial rebound depends on the degree of weakness and orientation, and how these features react to the changing postglacial stress field. If similar features (faults, blocks, etc.), as are present in Fennoscandia, exist in comparable locations of the Canadian craton, then we should expect similar pronounced fault offsets and block movements (e.g. Talvitie 1977; Morner 1978; Henkel 1978; Lagerback 1979; Lagerback and Witschard 1983; Bakkelid 1986) as have been observed in Fennoscandia. However if weak zones in the Canadian craton react in a different manner to the postglacial rebound stress field, then the extent of postglacial offsets and block movement would be different. The large areal extent, relative inaccessibility, ground cover and relatively few surveys directed specifically to the search for postglacial faults are several of the reasons why postglacial faults have not been documented in much of the Canadian craton. However the detailed studies of the spatiotemporal pattern of postglacial faulting and block movement in Fennoscandia are useful guidelines as to what we may expect in comparable locations in the Canadian craton.

\section{Horizontal strain rate}

Strain rates in a mid-continent (craton) environment are typically in the $10^{-14}$ to $10^{-16} / \mathrm{sec}$ range (Ranalli 1980, p. 1504), or, equivalently, $10^{-7}$ to $10^{-9} / \mathrm{yr}$, respectively. Fig. 26 shows that strains of this order-of-magnitude require space techniques, as other techniques do not have the required resolution. 


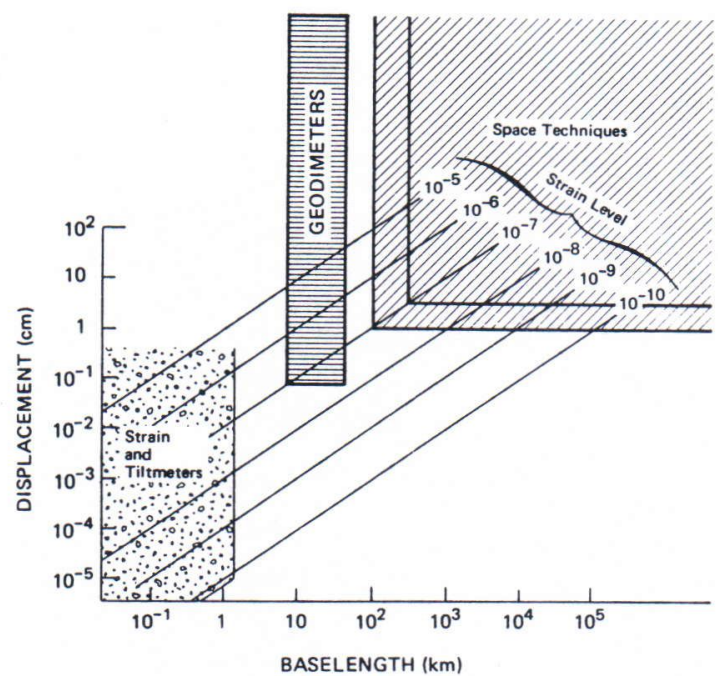

Fig. 26. Range of applicability, as function of baselength, of different types of strain measuring devices (from Instrumentation for measuring tectonic deformation 1981, p. 68).

Fig. 27 shows that Very-Long-Baseline Interferometry (VLBI) has the capability of detecting changes in length of $1 \mathrm{~cm}$ per year over a $2000 \mathrm{~km}$ baseline (Carter and Robertson 1986, p. 54). This corresponds to a strain rate of $5 \times$ $10^{-9} / \mathrm{yr}$, which falls in the range predicted by Ranalli. Strain rates measured across the midAtlantic ridge agree with predictions based on plate tectonic theory. The Canadian VLBI program is discussed by Cannon et al. (1979). Although comparable measurements have not been carried out in Canada, satellite (Doppler) techniques have been used to place greater precision on horizontal control points across Canada than previous determinations, which used land survey techniques (McLellan 1980, p. 7).

Contribution of the Geological Survey of Canada No. 28387.

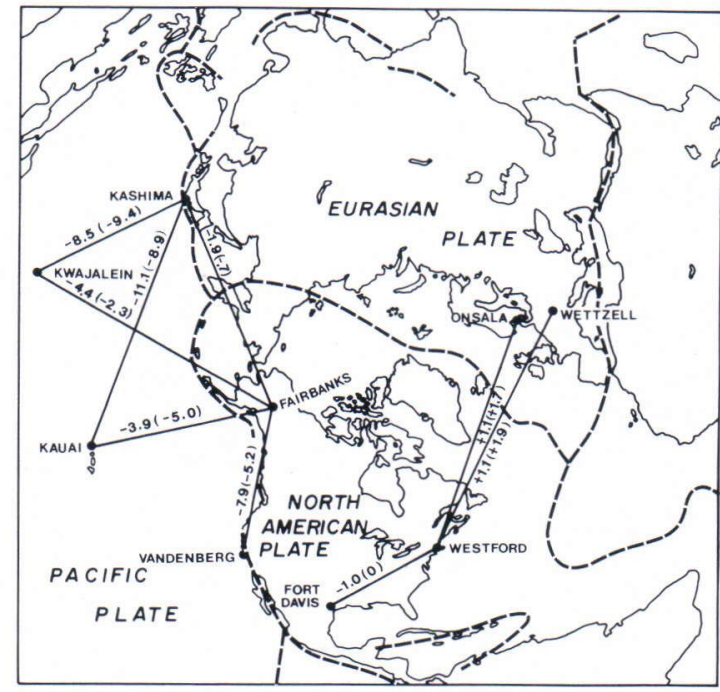

Fig. 27. Very-Long-Baseline Interferometry (VLBI) measurements $(\mathrm{cm} / \mathrm{yr})$. Number in brackets are plate motion predicted by theoretical model (from Carter and Robertson 1986).

Acknowledgement. The author wishes to thank the Nordic Liaison Committee for their kind invitation to me to present a talk on neotectonic movements in Canada. Much of the contents of that talk are described in this overview. However, the section on postglacial rebound has been expanded because of the mutual interest in this topic. Special thanks go to Dr. P. Vuorela for his personal invitation, to Mr. R. Lahtinen for his guidance, to Dr. A. Björklund for his encouragement to publish the talk and to the many members of the Nordic Liaison Committee for several interesting and informative field trips. J. R. Bowlby kindly sent a preprint of his paper on aggregate uplift. J. Wallach kindly sent some references on postglacial rebound in eastern Canada. Discussions with D. Wolf on postglacial rebound have been insightful and very helpful.

The author is grateful to the following for helpful comments: M. J. Berry, P. W. Basham, D. Wolf and D. A. Forsyth.

\section{References}

Adams, J., 1981. Postglacial faulting: a literature survey of occurrences in eastern Canada and comparable glaciated areas. At. Energy Can. Ltd., Techn. Rept TR-142, 1-63.
-, 1985. Canadian crustal stress data - a compilation to 1985. Energy, Mines and Resources Canada, Earth Physics Branch, Open File No. 85-31, 1-81. 
Andrews, J. T., 1970a. Present and postglacial rates of uplift for glaciated northern and eastern North America derived from postglacial uplift curves. Can. J. Earth. Sci. 7, 703-715.

- 1970b. Residual uplift. In A geomorphological study of postglacial uplift with particular reference to Arctic Canada. Institute of British Geographers, London, $125-132$.

Artyushkov, E. V., 1973. Stresses in the lithosphere caused by crustal thickness inhomogeneities. J. Geophys. Res. 78, 7675-7708.

Bakkelid, S., 1986. The determination of rates of land uplift in Norway. Tectonophysics 130, 307-326.

Barnett, D. M., 1966. A re-examination and re-interpretation of tide gauge data for Churchill, Manitoba. Can. J. Earth Sci. 3, 77-88.

- , 1970. An amendment and extension of tide gauge data analysis for Churchill, Manitoba. Can. J. Earth Sci. 7, $626-627$.

Basham, P. W.; Forsyth, D. A. \& Wetmiller, R. J., 1977. The seismicity of northern Canada. Can. J. Earth Sci. 14, 1646-1667.

Biswas, N. N.; Aki, K.; Pulpan, H. \& Tytgat, G., 1986. Characteristics of regional stresses in Alaska and neighboring areas. Geophys. Res. Let. 13, 177-180.

Bott, M. H. P.\& Dean, D. S., 1972. Stress systems at young continental margins. Nature Phys. Sci. 235, 23-25.

Bowlby, J. R., 1987. Redetermination of glacio-isostatic uplift and differential tilting of the Laurentide Great Lakes Basin. In International J. for Great Lakes Res. (in press).

Cannon, W. H.; Langley, R. B. \& Petrachenko, W. T., 1979. Geodesy and astrometry by transatlantic long base line interferometry. J. Geophys. Res. 84, 229-236.

Carter, W. E. \& Robertson, D. S., 1986. Studying the earth by very-long-baseline interferometry. Sci. Am. 255, $46-54$.

Clark, J. A., 1980. The reconstruction of the Laurentide ice sheet of North America from sea level data: method and preliminary results. J. Geophys. Res. 85, 4307-4323.

Covey, C., 1984. The earth's orbit and the ice ages. Sci. Am. $250,58-66$.

Doxsee, W. W., 1948. The Grand Banks earthquake of November 18, 1929. Publ. Dom. Observ. 7, 323-335.

Dragert, H., 1987. The fall (and rise) of central Vancouver Island: 1930-1985. Can. J. Earth Sci. 24, 689-697.

Evans, S. G.; Aitken, J. D.; Wetmiller, R. J. \& Horner, R. B., 1987. A rock avalanche triggered by the October 1985 North Nahanni earthquake, District of Mackenzie, N.W.T. Can. J. Earth Sci. 24, 176-184.

Forsyth, D. A., 1981. Characteristics of the western Quebec seismic zone. Can. J. Earth Sci. 18, 103-119.

-; Mair, J. A. \& Fraser, I., 1979. Crustal structure of the central Sverdrup Basin. Can. J. Earth Sci. 16, 1581-1598.

Frost, N. H. \& Lilly, J. E., 1966. Crustal movement in the
Lake St. John Area of Quebec. Can. Surveyor 20, 292-299.

Gough, D. I., 1986. Mantle upflow tectonics in the Canadian Cordillera. J. Geophys. Res. 91, 1909-1919.

Gutenberg, B. \& Richter, C. F., 1944. Frequency of earthquakes in California. Bull. Seism. Soc. Am. 34, 185-188.

— \& Richter, C. F., 1954. "Seismicity of the Earth», 2nd ed., Princeton University Press, Princeton, New Jersey, $308 \mathrm{p}$.

Hasegawa, H. S.; Chou, C. W. \& Basham, P. W., 1979. Seismotectonics of the Beaufort Sea. Can. J. Earth Sci. $16,816-830$.

-; Adams, J. \& Yamazaki, K., 1985. Upper crustal stresses and vertical stress migration in eastern Canada. J. Geophys. Res. 90, 3637-3648.

-, 1986. Seismotectonics in eastern Canada: an overview with emphasis on the Charlevoix and Miramichi regions. Earthq. Notes 57, 83-94.

Henkel, H., 1978. Dislocation sets in northern Sweden. Geol Foren. Stockh. Forth. 100, 271-278.

Instrumentation for measuring tectonic deformation, 1981. In Geodetic Monitoring of tectonic deformation - toward a strategy. National Academy Press, Washington, D.C., 66-92.

Jessop, A. M.; Lewis, T. J.; Judge, A. S.; Taylor, A. E. \& Drury, M. J., 1984. Terrestrial heat flow in Canada. Tectonophysics 103, 239-261.

Kasahara, K., 1979. Migration of crustal deformation. Tectonophysics 52, 329-341.

Keilis-Borok, V.\& Press, F., 1980. On seismological applications of pattern recognition. In Source mechanism and earthquake prediction, Editions du Centre National de la Recherche Scientifique, Paris, 51-60.

Kumarapeli, P. S. \& Saull, V. A., 1966. The St. Lawrence Valley system: a North American equivalent of the east African rift valley system. Can. J. Earth Sci. 3, 639-658.

Lagerback, R., 1979. Neotectonic structures in northern Sweden. Geol. Fören. Stockh., Förh. 100, 263-269.

— \& Witschard, F., 1983. Neotectonics in northern Sweden - geological investigations. Geol. Serv. Sweden, Tech. Rept. 83-58, 1-58.

Lambert, A. \& Vanicek, P., 1979. Contemporary crustal movements in Canada. Can. J. Earth Sci. 16, 647-668.

McLellan, C. D., 1980. Building a new framework for North America. GEOS, Spring 1980, 7-9.

Mogi, K., 1967. Earthquakes and fractures. Tectonophysics $5,35-55$.

—, 1985. Earthquake prediction. Academic Press, Orlando, $355 \mathrm{p}$.

Mörner, N.-A., 1978. Faulting, fracturing and seismicity as functions of glacio-isostasy in Fennoscandia. Geology 6, $41-45$.

Okulitch, A. V.; Packard, J. J. \& Zolnai, A. I., 1986. Evolution of the Boothia Uplift, arctic Canada. Can. J. Earth 
Sci. 23, 350-358.

Peltier, W. R., 1985. Mantle convection and viscoelasticity. Ann. Rev. Fluid Mech. 17, 561-608.

-, 1986. Deglaciation-induced vertical motion of the North American continent and transient lower mantle rheology. J. Geophys. Res. 91, 9099-9123.

-; Drummond, R. A. \& Tushingham, A. M., 1986. Postglacial rebound and transient lower mantle rheology. Geophys. J. R. Astr. Soc. 87, 79-116.

—; Farrell, W. E. \& Clark, J. A., 1978. Glacial isostasy and relative sea level: a global finite element model. Tectonophysics $50,81-110$.

— \&Wu, P., 1982. Mantle phase transitions and the free air gravity anomalies over Fennoscandia and Laurentia. Geophys. Res. Let. 9, 731-734.

Piper, D. J. W. \& Aksu, A. E., 1987. The source and origin of the 1929 Grand Banks turbidity current inferred from sediment budgets. Geo-marine Letters (in press).

— \& Normark, W. R., 1982. Effects of the 1929 Grand Banks earthquake on the continental slope off eastern Canada. In Current Research, Part B, Geol. Surv. Can., Paper 82-1B, 147-151.

—; Sparkes, R. \& Mosher, D. C., 1985. Seabed instability near the epicentre of the 1929 Grand Banks earthquake. Geol. Surv. Can., Open File Rept. 1131.

Press, F., 1965. Displacements, strains, and tilts at teleseismic distances. J. Geophys. Res. 70, 2395-2412.

Prest, V. K., 1970. Quaternary geology of Canada. In Douglas, R. J. W. (ed.) Geology and economic minerals of Canada. Geol. Surv. Can., Econ. Geol. Rept. 1, $676-764$.

Quinlan, G., 1984. Postglacial rebound and the focal mechanisms of eastern Canadian earthquakes. Can. J. Earth. Sci. 21, 1018-1023.

Ranalli, G., 1980. Rheological properties of the upper mantle in Canada from olivine microrheology. Can. J. Earth Sci. 17, 1499-1505.

Riddihough, R. P., 1977. A model for recent plate interactions off Canada's west coast. Can. J. Earth Sci. 14, 384-396.

-, 1982. Contemporary movements and tectonics on Canada's west coast: a discussion. Tectonophysics 86 , $319-341$.

Rogers, G. C.; Ellis, R. M. \& Hasegawa, H. S., 1980. The McNaughton Lake earthquake of May 14, 1978. Bull. Seism. Soc. Am. 70, 1771-1786.

- \& Hasegawa, H. S., 1978. A second look at the British Columbia earthquake of June 23, 1946. Bull. Seism. Soc. Am. 68, 653-675.

Sanford, B. W.; Thompson, F. J. \& McFall, G. H., 1984. Phanerozoic and recent tectonic movements in the Canadian shield and their significance to the nuclear fuel waste management program. In Proceedings on Workshop on transitional processes, Atom. Energy Can. Ltd.,
AECL-7822, 73-96.

-; Thompson, F. J. \& McFall, G. H., 1985a. Plate tectonics - a possible controlling mechanism in the development of hydrocarbon traps in southwestern Ontario. Bull. Can. Petrol. Geol. 33, 52-71.

—; Thompson, F. J. \& McFall, G. H., 1985b. Phanerozoic and recent tectonics of the Canadian craton. In Proceedings of the seventeenth information meeting of the Nuclear Fuel Waste Management Program. Atom. Energy Can. Ltd. TR-299, 334-352.

Sleep, N. H.; Kroeger, G. \& Stein, S., 1988. Canadian passive margin stress field inferred from seismicity. J. Geophys. Res. (in press).

Smith, W. E. T.; Whitham, K. \& Piche, W. T., 1968. A microearthquake swarm in 1965 near Mould Bay, N.W.T. Canada. Bull. Seism. Soc. Am. 58, 1991-2011.

Sobczak, L. W., 1975. Gravity and deep structure of the continental margin of Banks Island and MacKenzie delta. Can. J. Earth. Sci. 12, 378-394.

Stein, S.; Sleep, N. H.; Geller, R. J.; Wang, S-C. \& Kroeger, $G$. C., 1979. Earthquakes along the passive margins of eastern Canada. Geophys. Res. Let. 6, 537-540.

Talvitie, J., 1977. Seismotectonics of northern Finland and the Fennoscandian shield. Dept. Geophysics, Univ. Oulu, Finland, Contrib. 82, 27 p.

Talwani, P. 1986. Intersecting ideas - or the intersection model for intraplate earthquakes. Earthq. Notes 57, 13 (Abstract).

Turcotte, D. L.; Ahern, J. L. \& Bird, J. M., 1977. The state of stress at continental margins. Tectonophysics 42, 1-23.

— \& Schubert, G., 1982. GEODYNAMICS, Applications of Continuum Physics to Geological Problems. J. Wiley and Sons, New York, $450 \mathrm{p}$.

Vanicek, P., 1976. Pattern of recent vertical crustal movements in Maritime Canada. Can. J. Earth Sci. 13, $661-667$.

— \& Nagy, D., 1980. Report on the compilation of the map of vertical crustal movements in Canada. Earth Physics Branch Open File No. 80-2, Energy, Mines and Resources Canada, 59 p.

— \& Nagy, D., 1981. On the compilation of the map of contemporary vertical crustal movements in Canada. Tectonophysics 71, 75-86.

Walcott, R. I., 1970. Isostatic response to loading of the crust in Canada. Can. J. Earth Sci. 7, 716-727.

-, 1972. Late Quaternary vertical movements in eastern North America: quantitative evidence of glacio-isostatic rebound. Rev. Geophys. Space Phys. 10, 849-884.

Weichert, D. H.; Wetmiller, R. J. \& Munro, P., 1986. Vertical earthquake acceleration exceeding $2 \mathrm{~g}$ ? The case of the missing peak. Bull. Seism. Soc. Am. 76, 1473-1478.

Wetmiller, R. J.; Adams, J.; Anglin, F. M.; Hasegawa, H. S. \& Stevens, A. E., 1984. Aftershock sequences of the 1982 Miramichi, New Brunswick, earthquakes. Bull. 
Seism. Soc. Am. 74, 621-653.

— \& Forsyth, D. A., 1982. Review of seismicity and other geophysical data near Nares Strait. In Meddelelser om Grönland, Geoscience, 8, 261-274.

Wold, R. J.; Woodzick, T. L. \& Ostenso, N. A., 1970. Structure of the Beaufort Sea continental margin. Geophysics $35,849-861$.

Wolf, D., 1986a. Glacio-isostatic adjustment in Fennoscandia revisited. J. Geophys. 59, 42-48.
,$- 1986 \mathrm{~b}$. On deglaciation-induced perturbations of the geoid. Can. J. Earth Sci. 23, 269-272.

Zoback, M. D. \& Zoback, M. L., 1986. In-situ stress, lowercrustal strain, and intraplate seismicity. Earthq. Notes 57, 13 (Abstract).

Received September 10, 1987

Revised and accepted November 5, 1987 